Central Washington University

ScholarWorks@CWU

3-13-2013

Continuous monitoring reveals multiple controls on ecosystem metabolism in a suburban stream

Jake J. Beaulieu

Clay P. Arango

David A. Balz

William D. Shuster

Follow this and additional works at: https://digitalcommons.cwu.edu/biology

Part of the Environmental Health and Protection Commons, Environmental Indicators and Impact Assessment Commons, Environmental Monitoring Commons, and the Fresh Water Studies Commons 


\title{
Continuous monitoring reveals multiple controls on ecosystem metabolism in a suburban stream
}

\author{
JAKE J. BEAULIEU*, CLAY P. ARANGO ${ }^{\dagger}$, DAVID A. BALZ ${ }^{\ddagger}$ AND WILLIAM D. SHUSTER* \\ *United States Environmental Protection Agency, Office of Research and Development, National Risk Management Research Laboratory, \\ Cincinnati, OH, U.S.A. \\ ${ }^{\dagger}$ Department of Biological Sciences, Central Washington University, Ellensburg, WA, U.S.A.

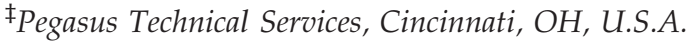

\section{SUMMARY}

1. Primary production and respiration in streams, collectively referred to as stream ecosystem metabolism, are fundamental processes that determine trophic structure, biomass and nutrient cycling. Few studies have used high-frequency measurements of gross primary production (GPP) and ecosystem respiration (ER) over extended periods to characterise the factors that control stream ecosystem metabolism at hourly, daily, seasonal and annual scales.

2. We measured ecosystem metabolism at 5-min intervals for 23 months in Shepherd Creek, a small suburban stream in Cincinnati, Ohio (U.S.A.).

3. Daily GPP was best predicted by a model containing light and its synergistic interaction with water temperature. Water temperature alone was not significantly related to daily GPP, rather high temperatures enhanced the capacity of autotrophs to use available light.

4. The relationship between GPP and light was further explored using photosynthesis-irradiance curves (P-I curves). Light saturation of GPP was evident throughout the winter and spring and the P-I curve frequently exhibited strong counterclockwise hysteresis. Hysteresis occurred when water temperatures were greater in the afternoon than in the morning, although light was similar, further suggesting that light availability interacts synergistically with water temperature.

5. Storm flows strongly depressed GPP in the spring while desiccation arrested aquatic GPP and ER in late summer and autumn.

6. Ecosystem respiration was best predicted by GPP, water temperature and the rate of water exchange between the surface channel and transient storage zones. We estimate that $c .70 \%$ of newly fixed carbon was immediately respired by autotrophs and closely associated heterotrophs.

7. Interannual, seasonal, daily and hourly variability in ecosystem metabolism was attributable to a combination of light availability, water temperature, storm flow dynamics and desiccation. Human activities affect all these factors in urban and suburban streams, suggesting stream ecosystem processes are likely to respond in complex ways to changing land use and climate.

Keywords: autotrophic respiration, desiccation, hysteresis, photosynthesis-irradiance curve

\section{Introduction}

Primary production and respiration in streams, collectively referred to as ecosystem metabolism, are fundamental ecosystem processes that determine trophic structure and biomass. Ecosystem metabolism is also an important driver of nutrient cycling and provides an integrative measure of stream ecosystem function. Advances in sensor technology and improvements in ecosystem assessment methods (Marzolf, Mulholland \& Steinman, 1994; Young \& Huryn, 1998) have allowed for an increasing number of ecosystem metabolism studies in

Correspondence: Jake J. Beaulieu, United States Environmental Protection Agency, Office of Research and Development, National Risk Management Research Laboratory, 26 W. MLK Dr. Cincinnati, OH 45268, U.S.A. E-mail: beaulieu.jake@epa.gov 
recent years (e.g. Fellows, Valett \& Dahm, 2001; Acuña et al., 2004; Bott, Newbold \& Arscott, 2006) which have substantially improved our understanding of the factors controlling gross primary production (GPP) and ecosystem respiration (ER).

An important factor controlling GPP in streams is light availability at the sediments (Mulholland et al., 2001; Roberts, Mulholland \& Hill, 2007). Potential light availability is governed by latitude and season, but local factors such as shading, turbidity and aspect can strongly influence light transmission to the stream and sediments (Young \& Huryn, 1999). Nutrient supply can also be an important control on primary producers and heterotrophs (Mulholland et al., 2001). Similarly, autotrophs and heterotrophic microbes require carbon, but autotrophs utilise inorganic sources, whereas heterotrophs require organic forms, so seasonal leaf fall can regulate heterotrophic activity by controlling organic matter quantity and quality (Webster \& Meyer, 1997). Other factors that influence stream metabolism include water temperature (Demars et al., 2011b), desiccation (Dodds et al., 1996) and storm flows (Uehlinger \& Naegeli, 1998). All these factors can be strongly influenced by anthropogenic impacts on basin hydrology and nutrient status.

Small streams draining urban and suburban basins exhibit a consistent suite of physical, chemical and biological impairments that have been termed the 'urban stream syndrome' (Meyer, Paul \& Taulbee, 2005; Walsh et al., 2005), and many of these factors can control stream ecosystem metabolism. Hydrographs characterised by rapid ascending and descending limbs and large storm flow volumes are perhaps the most consistent characteristic of urban streams. This 'flashy' hydrology can suppress stream ecosystem metabolism through frequent and intense physical disturbance of the benthos. At the other extreme, reduced groundwater recharge in urban basins may decrease stream baseflow and increase the frequency of stream drying (Walsh et al., 2005). Other changes to urban streams, such as increased nutrient enrichment from managed landscapes, elevated water temperatures from stormwater run-off (Herb et al., 2008) and carbon inputs from leaky sewers may stimulate stream metabolism. Superimposed on these local scale changes are larger-scale perturbations driven by climate change, such as increased temperature and fewer, but more intense precipitation events that could increase the frequency of extreme high and low flows. Resolving the net effect of these simultaneous pressures on stream ecosystem metabolism is an important research and management challenge.
Several studies have examined controls on ecosystem metabolism in streams draining suburban or urban basins (Meyer et al., 2005; Bernot et al., 2010; Sudduth et al., 2011), but these only measured stream metabolism over a few days during stable flows in one or two seasons. The relatively short duration of these investigations limits our ability to identify important longer-term controls on stream metabolism. For example, GPP and ER frequently exhibit distinct seasonal patterns. Similarly, annual rates of GPP and ER vary strongly between years, based on the frequency and duration of disturbances such as storm flows and desiccation (Roberts et al., 2007). Another limitation of most investigations is that they are typically conducted during stable flows and weather. Storm flows can have a strong effect on stream metabolism for days after the event, and this may be particularly important in flashy urban and suburban streams. The efficacy of shortterm studies in identifying controlling factors is further limited by the sample sizes, which typically range from 10 to 50 measurements per study.

Many of the limitations of short-term studies can be alleviated by the continuous monitoring of stream metabolism. Recent advances in sensor technology have made possible the continuous measurement of dissolved oxygen (DO) with high accuracy and precision, and several recent investigations have demonstrated that the continuous monitoring of ecosystem metabolism in streams (Roberts et al., 2007; Izagirre et al., 2008) and rivers (Uehlinger, 2006; Hunt et al., 2011) is possible and can reveal temporal patterns not apparent with lower-frequency measurements. This implies that measurements taken with relatively high temporal resolution will improve our understanding of stream ecosystem metabolism, improving our ability to predict how streams will respond to changing land use and climate.

In this study, we investigated the controls on ecosystem metabolism in Shepherd Creek, a small suburban stream in Cincinnati, $\mathrm{OH}$ (U.S.A.), using 23 months of continuous monitoring, combined with less frequent measures of potential controlling factors, including water chemistry and transient storage. We analysed these data using statistical tools that account for temporal autocorrelation and report interannual, seasonal, daily and hourly patterns in ecosystem metabolism. We predicted that (i) light, nutrients and water temperature would control GPP; (ii) that ER would depend on water temperature, transient storage, GPP and, possibly, dissolved organic carbon (DOC) from leaky sewers and (iii) that seasonal scale patterns would be modified by less predictable storm flows that would add stochastic variability to GPP and ER. 


\section{Methods}

Study site

Shepherd Creek is a second-order intermittent stream in Cincinnati (Hamilton County), Ohio, U.S.A. $\left(39^{\circ} 34^{\prime} \mathrm{N}\right.$, $84^{\circ} 34^{\prime} \mathrm{W}$ ) draining a 26.3 ha mixed land use basin composed of calcareous shale and limestone formations that have weathered to predominantly silt loam and silty clay loam soils (Shuster, Gehring \& Gerken, 2007). The eastern half of the basin lies within a city park with mature deciduous forest while the western and central portions of the basin drain a mix of residential developments and open fields. Impervious surfaces compose $11.2 \%$ of the basin, with $5.4 \%$ of the impervious area directly connected to the stream through stormwater drains (Roy \& Shuster, 2009). The riparian zone overstory is composed of native deciduous trees [e.g. sycamore (Platanus occidentalis)], and the understory was dominated by non-native honeysuckle (Lonicera maackii).

The area has mean annual air temperature and precipitation of $12.5^{\circ} \mathrm{C}$ and $110 \mathrm{~cm}$, respectively. Warm and humid summers have a mean maximum temperature of $30.6{ }^{\circ} \mathrm{C}$ in July, although temperatures commonly exceed $32{ }^{\circ} \mathrm{C}$, and winters have a mean minimum of $-5.2{ }^{\circ} \mathrm{C}$ in January and an annual mean snowfall of $50 \mathrm{~cm}$.

Stream flows in Shepherd Creek are highly seasonal, with peak flows during winter and spring and lowest flows usually in August, when the stream can dry to a series of isolated pools. Stream flow responds rapidly to precipitation throughout the year.

Stream sediments are composed of silt, gravel and cobbles, with substantial sections of exposed bedrock upstream of the metabolism study reach. The stream channel has been incised and widened from increased run-off volume associated with the expansion of the impervious surfaces in the basin during the past century (Paul \& Meyer, 2001).

\section{Dissolved oxygen and temperature}

Dissolved oxygen and water temperature were recorded at 5-min intervals from 1 July 2009 to 31 May 2011 at two monitoring stations separated by $28 \mathrm{~m}$, equivalent to a water travel time of 5-50 min. DO and temperature were measured using YSI 600-OMS V2 data sondes with YSI 6150 optical DO sensors (YSI, Yellow Springs, OH, U.S.A.). One sonde was placed at each station for 7 days, although deployments lasted as long as 11 days (i.e. the duration of the batteries) and as short as 4 days. At the end of each deployment, the sondes were replaced with two freshly calibrated sondes. DO was calibrated in the laboratory using the water-saturated air method prior to deployment, and the calibration was checked at the end of the deployment. At the beginning and end of each deployment, the sondes from the upstream and downstream stations were placed side by side in the stream for $20 \mathrm{~min}$ and DO recorded every $2 \mathrm{~min}$. All DO data were corrected for calibration drift during the deployment and for any residual differences between sondes. This procedure assured that any differences in $\mathrm{DO}$ between the upstream and downstream monitoring stations could not be attributed to analytical error. Percent saturation was calculated from water temperature, DO concentration and barometric pressure recorded continuously at a local airport.

Light

Photosynthetically active radiation (PAR) was recorded at 5-min intervals from 23 June 2010 to 31 May 2011 using Photosynthetic Irradiance Sensors (Odyssey, Christchurch, New Zealand) deployed c. $1 \mathrm{~m}$ above the water surface at the upstream and downstream monitoring stations. The sensors were calibrated against a quantum sensor (LI-190; LI-COR, Lincoln, NE, U.S.A.) under natural sunlight (Shaffer \& Beaulieu, 2012) immediately before each $c$. 7-day deployment.

\section{Discharge}

From 1 July 2009 to 1 July 2010, discharge was recorded at 5 -min intervals using a $120^{\circ}-\mathrm{v}$ notch weir and bubble water level sensor located $180 \mathrm{~m}$ downstream from the study reach. We noted that flow in the metabolism reach was greater than at the weir, so an additional bubble water level sensor was installed $60 \mathrm{~m}$ downstream from the metabolism reach on 3 December 2009, and stage was recorded at 5-min intervals. The two monitoring sites were intercalibrated, and from 1 July 2009 to 3 December 2010, calibrated discharge data from the weir were used in the metabolism calculations. Discharge data from the new monitoring station were used in the metabolism calculations for the balance of the study.

\section{Gas exchange rates}

We took 14 measurements of the gas exchange rate $\left(k\right.$, units of day $\left.{ }^{-1}\right)$ across a range of discharge conditions between 20 October 2009 and 22 July 2010 using the steady-state tracer gas method (Wanninkhof, Mulholland \& Elwood, 1990; Genereux \& Hemond, 1992) corrected for dilution using rhodamine, a conservative tracer. 
Sulphur hexafluoride $\left(\mathrm{SF}_{6}\right)$ was bubbled into the stream at a constant rate while rhodamine was metered into the stream using a reciprocating piston pump (Fluid Metering Inc, Syosset, NY, U.S.A.). The injection site was located $10-40 \mathrm{~m}$ above the most upstream sampling station, depending on discharge, and we confirmed that the solutes were well mixed at the sampling station by measuring rhodamine via fluorescence across the width of the stream using a YSI 6600 sonde and 6130 rhodamine probe. The site was considered well mixed if rhodamine varied no more than $5 \%$ across the stream width. Rhodamine was monitored continuously at the top and bottom of the metabolism reach during the tracer release. Once the tracers reached steady state throughout the reach, five replicate $\mathrm{SF}_{6}$ samples were taken from the top and bottom of the reach by collecting $2.5 \mathrm{~mL}$ of stream water in a 5-mL syringe and injecting the water into a pre-evacuated $5 \mathrm{~mL}$ Vacutainer (BD, Franklin Lakes, NJ, U.S.A.). Headspace $\mathrm{SF}_{6}$ concentration was measured by injecting $10-100 \mu \mathrm{L}$ of gas into a Shimadzu GC-17A gas chromatograph (Columbia, MD, U.S.A.) equipped with a Q-Plot capillary column and ECD detector. Detector and column temperatures were 300 and $55^{\circ} \mathrm{C}$, respectively.

The air-water gas exchange rate was calculated according to

$$
\ln \left[\mathrm{SF}_{6}\right]_{x}=\ln \left[\mathrm{SF}_{6}\right]_{0}-(a * x)
$$

where $\left[\mathrm{SF}_{6}\right]_{x}$ is the dilution-corrected $\mathrm{SF}_{6}$ concentration $x \mathrm{~m}$ downstream from the addition site and at the most upstream station $\left(\left[\mathrm{SF}_{6}\right]_{0}\right)$, and $a$ is the rate constant for $\mathrm{SF}_{6}$ loss per metre of stream channel, which was converted to $k_{\mathrm{SF}_{6}}$ by multiplying by water velocity $(v)$. The oxygen gas exchange rate $\left(k_{\mathrm{O}_{2}}\right)$ was calculated as $k_{\mathrm{SF}_{6}}{ }^{*} 1.345$ based on the relative values of their Schmidt numbers (Macintyre, Wanninkhof \& Chanton, 1995).

Water velocity $(v)$ during the tracer release was calculated from the time required for the rhodamine concentration at the bottom station to reach half of the maximum value (i.e. time to half height). Stream discharge $(Q)$ was calculated as:

$$
Q=\frac{Q_{\text {pump }} \times R h_{\text {inj }}}{\left(R h_{\text {plt }}-R h_{\text {bck }}\right)}
$$

where $Q_{\text {pump }}$ and $\mathrm{Rh}_{\text {inj }}$ are the injection rate and rhodamine concentration for the rhodamine solution, respectively. $R h_{\text {plt }}$ and $R h_{\text {bck }}$ are the plateau and background rhodamine concentrations at the downstream station, respectively. Stream-wetted width $(w)$ was measured at 1-m intervals along the length of the stream during each tracer release. Effective stream depth $(z)$ was calculated as $Q /(w v)$.

The metabolism calculations require a $k_{\mathrm{O}_{2}}$ value for each measurement of $\mathrm{DO}$, water temperature and discharge. To estimate $k_{\mathrm{O}_{2}}$ throughout the study, we developed an empirical relationship between gas exchange rates and discharge. To account for the influence of water temperature on gas exchange, all measured $k_{\mathrm{O}_{2}}$ values were corrected to $20{ }^{\circ} \mathrm{C}$ according to

$$
k_{\mathrm{O}_{2} \text { at } 20^{\circ} \mathrm{C}}=k_{\mathrm{O}_{2}-T} /(1.0241)^{T-20}
$$

Where $k_{\mathrm{O}_{2} \text { at } 20^{\circ} \mathrm{C}}$ is $k$ for $\mathrm{O}_{2}$ at $20{ }^{\circ} \mathrm{C}$, and $k_{\mathrm{O}_{2}}-T$ is $k$ for $\mathrm{O}_{2}$ measured at water temperature $T$ (Elmore \& West, 1961). The $k_{\mathrm{O}_{2}}$ at $20^{\circ} \mathrm{C}$ predicted from the $k_{\mathrm{O}_{2}}$-discharge relationship was then corrected to ambient stream water temperature at each measurement interval for the metabolism calculations. We also developed relationships that allowed us to predict water depth and velocity from discharge at each measurement interval.

The highest flow under which $k$, depth, velocity and width were measured was $17 \mathrm{~L} \mathrm{~s}^{-1}$. We did not extrapolate outside of the calibration range for our models, and therefore, metabolic parameters were not calculated when $\mathrm{Q}$ exceeded $17 \mathrm{~L} \mathrm{~s}^{-1}$. We did, however, calculate daily metabolic parameters on days when $\mathrm{Q}$ exceeded $17 \mathrm{~L} \mathrm{~s}^{-1}$ if the following conditions were met: (i) If $Q>17 \mathrm{~L} \mathrm{~s}^{-1}$ was restricted to the hours of darkness and (ii) $Q$ was $<17 \mathrm{~L} \mathrm{~s}^{-1}$ for at least $2 \mathrm{~h}$ prior to sunrise or after sunset. Under these conditions, we assumed that ER during the high-flow period was equal to the average ER measured during the low-flow period. If $Q$ exceeded $17 \mathrm{~L} \mathrm{~s}^{-1}$ outside of these criteria, daily metabolic rates were not calculated. The rationale for this approach is that ER exhibits less diel variability than GPP; we were therefore able to extrapolate ER measurements.

\section{Transient storage}

We used OTIS-P (Runkel, 1998) to fit the rhodamine breakthrough curve recorded at the bottom of the experimental reach to a one-dimensional advection, dispersion and transient storage model. The OTIS-P model estimates solute exchange parameters such as the cross-sectional area of the transient storage zone $\left(A_{\mathrm{s}}\right)$ and the storage zone exchange coefficient $(\alpha)$. From these parameters, we calculated the storage zone residence time $\left(T_{\text {sto }}\right)$

$$
T_{\text {sto }}=A_{\mathrm{s}} / \alpha * A
$$




\section{J. J. Beaulieu et al.}

where $A$ is the cross-sectional area of the stream channel calculated from the rhodamine breakthrough curve and channel measurements. We calculated the storage exchange flux $\left(q_{\mathrm{s}}\right)$

$$
q_{\mathrm{s}}=\alpha A
$$

which represents the average water flux through the storage zone per unit length. We also calculated fraction of the median travel time due to transient storage, $F_{\text {med }}^{200}$ (Runkel, 2002). To estimate whether the reach length was appropriate for measuring transient storage parameters, we calculated the Damkohler number (DaI; Harvey \& Wagner, 2000) for each tracer release. Damkohler numbers between 0.5 and 5 indicate the transient storage parameters could be estimated reliably estimated.

\section{Metabolism calculations}

We calculated ER and GPP using the one- and two-station diel DO methods. The two-station calculations followed Marzolf et al. (1994) with the corrections discussed in Young \& Huryn (1998), and the one-station calculations followed Roberts et al. (2007). Both methods assume that changes in $\mathrm{DO}(\Delta \mathrm{DO})$ as a unit volume of water travels through a stream reach can be attributed to photosynthesis, respiration and gas exchange. The change in dissolved oxygen $(\Delta \mathrm{DO})$ for the two-station method was calculated as the difference in DO between the upstream and downstream stations one travel time-interval later (or closest 5-min interval). In the one-station method, $\Delta \mathrm{DO}$ was calculated as the difference between consecutive 5min readings at one station. The mass balance equation governing $\triangle \mathrm{DO}$ is as follows:

$$
\Delta \mathrm{DO}=\mathrm{GPP}-\mathrm{ER}+E
$$

where $E$, the net exchange of $\mathrm{O}_{2}$ with the atmosphere, was calculated based on the DO saturation or deficit in the reach and $k_{\mathrm{O}_{2}}$ which was estimated from our empirical discharge $-k_{\mathrm{O}_{2}}$ relationship. The net rate of oxygen change as a result of metabolism (net ecosystem production, NEP) was then determined from the change in DO mass flux across the study reach after correcting for $E$. During the night hours, GPP was assumed to be zero, and NEP was equal to ER. Daytime ER was estimated by interpolating ER values measured $1 \mathrm{~h}$ pre-dawn and post-sunset (Mulholland et al., 2001). GPP for each measurement interval was then calculated as the difference between NEP and the interpolated ER. Daily rates of ER and GPP were determined by summing the 5-min rates over each 24-h period. Daily rates calculated on a volumetric basis using the one-station method $\left(\mathrm{g} \mathrm{O}_{2} \mathrm{~m}^{-3}\right.$ day $\left.^{-1}\right)$ were converted into areal units $\left(\mathrm{g} \mathrm{O}_{2} \mathrm{~m}^{-2}\right.$ day $\left.^{-1}\right)$ by multiplying by effective water depth determined from the discharge-effective depth relationship. Daily rates calculated on a per-reach basis (e.g. $\mathrm{g} \mathrm{O}_{2}$ reach $^{-1}$ day $^{-1}$ ) using the two-station method were converted into areal units by dividing by the area of stream bottom between the two stations determined from reach length and the dischargewidth relationship.

\section{Photosynthesis-irradiance curves}

To gain additional insight into daily and seasonal patterns in GPP, we constructed photosynthesis-irradiance curves from 23 June 2010 to 31 May 2011, when PAR and GPP were available at 5-min intervals. For each day the stream was flowing during this period, we fitted the instantaneous GPP versus PAR relationship with the twoparameter photosynthesis-irradiance (P-I) curve of Jassby \& Platt (1976):

$$
P=P_{\max } \tan h\left(\frac{\alpha I}{P_{\max }}\right) .
$$

where $P$ is GPP at a given irradiance, $P_{\max }$ is the maximum GPP, $\alpha$ is the slope of the initial part of the curve and $I$ is PAR (i.e. irradiance). Maximum GPP $\left(P_{\max }\right)$ and $\alpha$ were estimated using the nonlinear least squares fitting package, nls, in $\mathrm{R}$ ( $\mathrm{R}$ Development Core Team, 2011). The PAR intensity at which photosaturation begins, $I_{k}$, was calculated as $P_{\max } / \alpha$ (Platt, Gallegos \& Harrison, 1980). The three-parameter mode of Platt et al. (1980) was not used because there was no evidence of photoinhibition in the P-I curves.

\section{Nutrients}

Filtered $(0.45 \mu \mathrm{m})$ and unfiltered water samples were collected from the stream approximately every 2 weeks throughout the duration of the study. Total organic carbon (TOC) and DOC samples were preserved with sulphuric acid $(\mathrm{pH}<2)$, stored at $4{ }^{\circ} \mathrm{C}$ and analysed within 28 days using a Shimadzu TOC-V with catalytic combustion and NDIR detection. Unfiltered total suspended solids samples were stored at $4{ }^{\circ} \mathrm{C}$ and analysed gravimetrically (APHA, 2005) within 7 days. The remaining samples were stored at $4{ }^{\circ} \mathrm{C}$ and analysed within $24 \mathrm{~h}$ or frozen and analysed within 7 days. Total phosphorus analysis consisted of an acid persulphate wet oxidation method followed by automated colorimetric analysis 
(Prokopy, 1992). Total nitrogen was measured by making adjustments to an alkaline oxidative persulphate method (APHA, 2005) followed by automated colorimetric analysis for nitrate (Wendt, 1995). Soluble reactive phosphorus (SRP), nitrite + nitrate $\left(\mathrm{NO}_{2}^{-}+\mathrm{NO}_{3}^{-}\right)$and ammonium $\left(\mathrm{NH}_{4}^{+}\right)$were analysed simultaneously with automated colorimetry by adjusting single analyte methods (Wendt, 1995; Sardina, 2000; Smith, 2001, respectively). All samples for nutrients were run on a Lachat Instruments QuickChem 8000 Flow Injection Autoanalyzer (Loveland, CO, U.S.A.).

\section{Statistical analysis}

Relationships between ecosystem metabolism rates and environmental parameters (e.g. water temperature, PAR, nutrients, etc.) were assessed using generalised least squares. Model covariates with a variance inflation factor, a measure of collinearity, $>1.5$ were excluded from the model (Neter, Wasserman \& Kutner, 1990). Models that produced temporally autocorrelated residuals were modified to include a first-order autoregressive correlation structure. Heterogeneity in models (e.g. increasing or decreasing residual spread along an explanatory variable) was reduced by incorporating an alternative variance structure (Zuur et al., 2009). The best variance and autocorrelation structures were chosen based on the Akaike information criterion values of competing models (Akaike, 1974). Model goodness-of-fit was assessed by comparing predicted and observed values using Pearson's product moment coefficient.

Conditional relationships between independent and dependent variables were assessed using quantile regression (Cade \& Noon, 2003). Conditional relationships between GPP and PAR were further explored using an analysis of covariance with the presence or absence of ice cover on the stream surface as a covariate.

The effect of storm pulses on ER and GPP was examined using a paired $t$-test based on pre-storm and post-storm metabolism rates. The effect of individual storms on GPP was qualitatively assessed by visual examination of pre-storm and post-storm P-I curves.

We defined seasons based on water temperature. Winter was defined as the period of low and stable water temperature (December 1-February 15); autumn (September 15-December 1) and spring (February 15-May 20) were periods of rapidly changing water temperature, and summer was the period of high and stable water temperature (May 20-September 15).

All statistical analyses were conducted in R ( R Development Core Team, 2011). Autocorrelation and alternative variance structures were incorporated into generalised least squares models using the nlme package (Pinheiro et al., 2011). Quantile regression was implemented with the quantreg package (Koenker, 2011).

\section{Results}

\section{Light, hydrology and nutrients}

Photosynthetically active radiation showed a predictable seasonal cycle of low values during the summer, when the canopy shaded the stream, and higher values after leaf senescence (Fig. 1a). Daily integrated PAR values $<0.5 \mathrm{~mol} \mathrm{~m}^{-2}$ day $^{-1}$ were common during the first half of June 2010, but by November 2010, the daily average was $3.7 \mathrm{~mol} \mathrm{~m}^{-2}$ day $^{-1}$. The highest weekly mean PAR values of $10.0 \mathrm{~mol} \mathrm{~m}^{-2}$ day $^{-1}$ occurred during the first week of April 2010, after which PAR declined rapidly to a weekly mean of $1.8 \mathrm{~mol} \mathrm{~m}^{-2}$ day $^{-1}$ at the end of May 2011

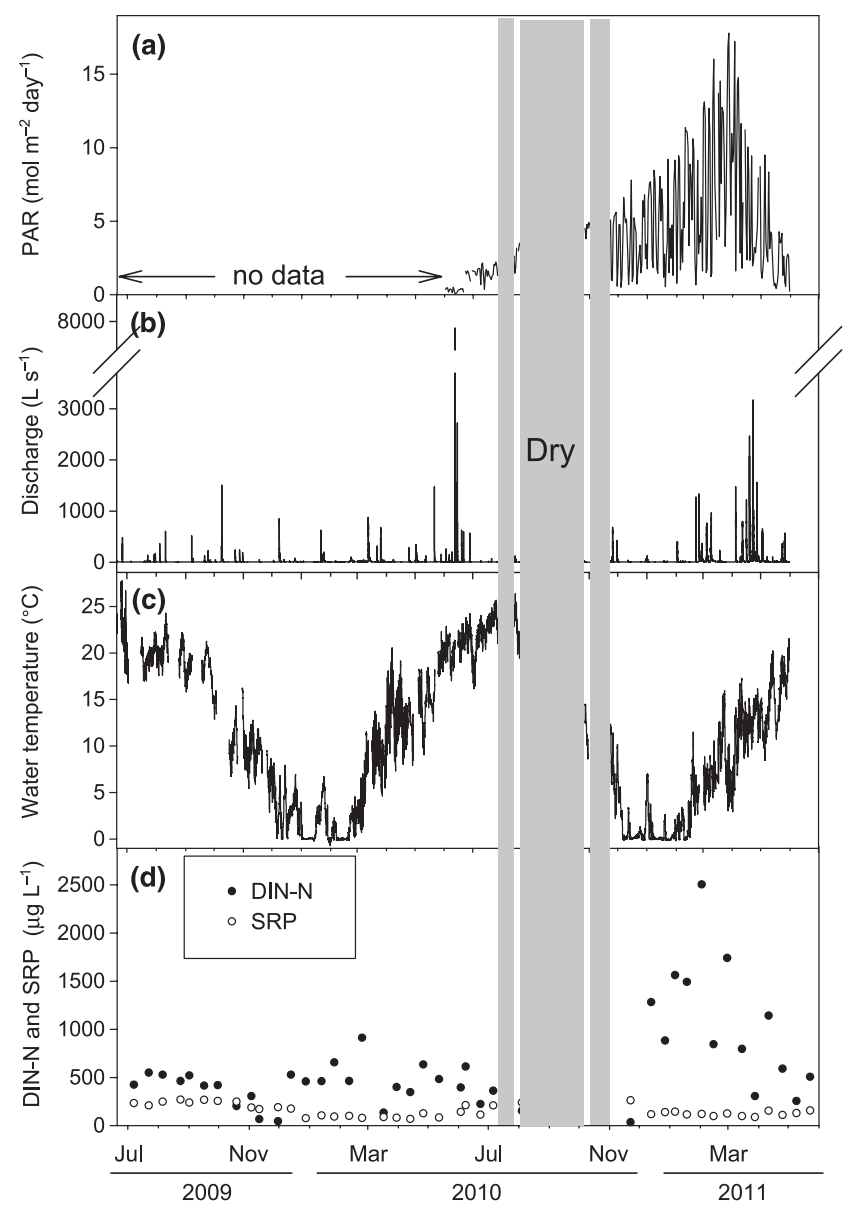

Fig. 1 (a) Photosynthetically active radiation (PAR) $1 \mathrm{~m}$ above the stream surface, (b) discharge $\left(\mathrm{L} \mathrm{s}^{-1}\right)$, (c) water temperature $\left({ }^{\circ} \mathrm{C}\right)$ and (d) dissolved inorganic nitrogen (DIN) and soluble reactive phosphorus (SRP) in Shepherd Creek from July 2009 to June 2011. 
$924 J$. J. Beaulieu et al.

as the riparian canopy developed. Superimposed on this seasonal pattern was strong day-to-day variation driven by transient cloud cover. The average weekly coefficient of variation of daily PAR values was 50\%.

Mean daily stream flow in Shepherd Creek was seasonal with the highest base flow observed in the winter and spring (3.9, $5.6 \mathrm{~L} \mathrm{~s}^{-1}$, respectively) and the lowest in the summer and autumn $\left(2.0,1.5 \mathrm{~L} \mathrm{~s}^{-1}\right.$, respectively; Fig. 1b). During dry years, stream flow can be intermittent, as seen in 2010 when flow ceased from July to November, with the exception of a few days following storms. By contrast, the stream flowed continuously in 2009. The storm hydrographs were characterised by rapid rates of rise and fall with large peak storm flow volumes.

Mean daily water temperature exhibited a strong seasonal pattern (Fig. 1c). Minimum values of $0{ }^{\circ} \mathrm{C}$ occurred during the winter, and the stream was partially ice covered for 27 days during winter 2009-10 and 31 days during winter 2010-11. A maximum temperature of c. $26^{\circ} \mathrm{C}$ occurred during the summers of 2009 and 2010.

Dissolved organic carbon averaged $4.5 \mathrm{mg} \mathrm{L}^{-1}$ and briefly spiked to $c .10 \mathrm{mg} \mathrm{L}^{-1}$ during autumn 2011 following a prolonged period of desiccation (Table S1). SRP concentration averaged $152 \mu \mathrm{g} \mathrm{P} \mathrm{L}{ }^{-1}$ (range: 60-342) and was lower during the winter and spring than summer and autumn $(P<0.001$, Fig. 1 d). Dissolved inorganic nitrogen (DIN) averaged $590 \mu \mathrm{g} \mathrm{N} \mathrm{L}^{-1}$ (range: $24-2494$ ) and was usually dominated by $\mathrm{NO}_{3}^{-}$(median $=96 \% \mathrm{NO}_{3}^{-}$). Ammonium ranged from 1 to $98 \mu \mathrm{g} \mathrm{N} \mathrm{L}^{-1}$ but was typically $<20 \mu \mathrm{g} \mathrm{N} \mathrm{L}^{-1}$ (median = 17). DIN fell to $25 \mu \mathrm{g} \mathrm{N} \mathrm{L}{ }^{-1}$ during the autumn of 2009, but rapidly rebounded to $>1000 \mu \mathrm{g} \mathrm{N} \mathrm{L}{ }^{-1}$ by early December, 2011. The full suite of water chemistry measurements can be found in Table S1.

\section{Transient storage}

We measured transient storage parameters approximately every 2 weeks from 8 July 2009 to 24 June 2010 (Table 1) and over a range of stream discharge of 0.40 $17.1 \mathrm{~L} \mathrm{~s}^{-1}$. The DaI number was between 0.5 and 5.0, the range which yields reliable transient storage parameter estimates, for 20 of the 21 tracer releases. The one tracer release with a $\mathrm{DaI}<0.5$ was omitted from the analysis (Table 1). Relative size of the transient storage zone $\left(A_{\mathrm{s}} / A\right)$ ranged from 0.16 to 0.55 (Table 1 ) and was negatively related to discharge $\left(P=0.027, r^{2}=0.23\right)$ and water velocity $\left(P=0.031, r^{2}=0.22\right)$. Higher discharge was associated with lower contributions of transient storage to water travel time ( $F_{\text {med; }}^{200}$ Table $1, r^{2}=0.36, P=0.004$ ) and lower transient storage zone residence times $\left(T_{\text {sto; }}\right.$;

Table 1 Transient storage parameters measured in Shepherd Creek between July 2009 and June 2010

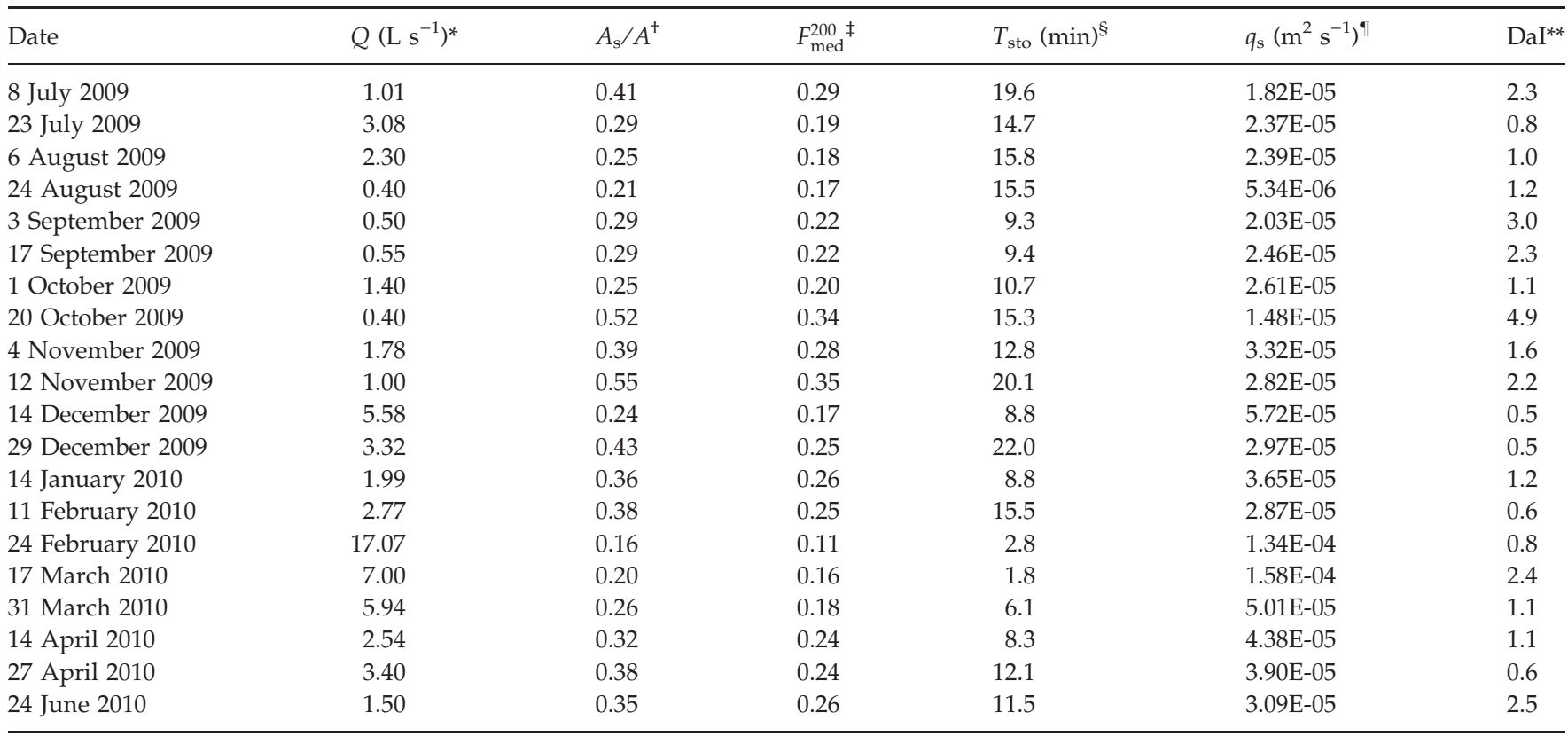

${ }^{*} Q$ is discharge.

${ }^{+} A_{\mathrm{s}} / A$ is the ratio of the theoretical cross-sectional area of the transient zone to that of the stream channel.

${ }^{\ddagger} F_{\text {med }}^{200}$ is the fraction of the median water travel time through the reach standardised to a reach length of $200 \mathrm{~m}$.

${ }^{\S} T_{\text {sto }}$ is the storage zone residence time.

${ }^{\top} q_{\mathrm{s}}$ is the storage exchange flux.

${ }^{* *} \mathrm{DaI}$ is the dimensionless Damkohler number. 
Table $\left.1 ; r^{2}=0.28, P=0.01\right)$. Storage exchange flux $\left(q_{\mathrm{s}}\right)$ varied over an order of magnitude and was negatively related to water velocity $\left(P<0.001, r^{2}=0.70\right)$.

\section{Gas exchange, width, depth and velocity}

We took 15 measurements of stream width, 22 measurements of water velocity and 14 measurements of $k_{\mathrm{O}_{2}}$ at discharge values ranging from 0.2 to $17 \mathrm{~L} \mathrm{~s}^{-1}$. Wetted width at base flow in the deeply incised channel was typically much less than the $3.1 \mathrm{~m}$ width of the active channel. Wetted width increased linearly with discharge up to $7.2 \mathrm{~L} \mathrm{~s}^{-1}$ and, at greater flows, stream depth and velocity increased, but wetted width remained constant until the stream spilled into the floodplain (Fig. 2a). Water velocity ranged from 0.6 to $6.9 \mathrm{~m} \mathrm{~min}^{-1}$ and was strongly correlated with discharge (Fig. 2b). Gas exchange rates for oxygen at $20{ }^{\circ} \mathrm{C}$ ranged from 24 to 217 per day and were modelled as a function of discharge using a two-parameter exponential model (Fig. 2c). The model explained $82 \%$ of the variation in the data and was used to predict $k_{\mathrm{O}_{2}}$ at $20^{\circ} \mathrm{C}$ for each $Q, D O$ and temperature measurement interval where $Q<17 \mathrm{~L} \mathrm{~s}^{-1}$. We measured gas exchange under ice cover on one occasion $\left(Q=1.4 \mathrm{~L} \mathrm{~s}^{-1}, k_{\mathrm{O}_{2} \text { at } 20^{\circ} \mathrm{C}}=34\right.$ day $\left.^{-1}\right)$, and the measurement did not differ substantially from measurements taken on ice-free days under similar discharge, possibly because the ice was suspended above the flowing water in some areas and did not cover the entire stream width in others. We did not apply a correction to the gas exchange estimate when ice was present.

\section{Temporal patterns in GPP, ER and NEP}

Daily metabolic parameters were calculated using either the one- or two-station approaches on 380 and 388 days of the 700 day study, respectively. Between the two methods, we estimated ecosystem metabolism on 402 separate days. We were unable to calculate daily metabolic parameters on 100 days when the stream was not flowing, 87 days when stream flow exceeded $17 \mathrm{~L} \mathrm{~s}^{-1}$ between dawn and dusk and 111 days when DO data were missing or of questionable quality.

Metabolism calculated using data from the downstream station integrates metabolism over a reach extending upstream by a length defined as three times the ratio of the water velocity and $k_{\mathrm{O}_{2}}$ (Chapra \& Di Toro, 1991). This distance ranged from 70 to $150 \mathrm{~m}$ over the range of discharge for which we calculated metabolism (e.g. $\leq 17 \mathrm{~L} \mathrm{~s}^{-1}$ ), which is substantially greater than the twostation reach length (e.g. $28 \mathrm{~m}$ ). According to this calcu-

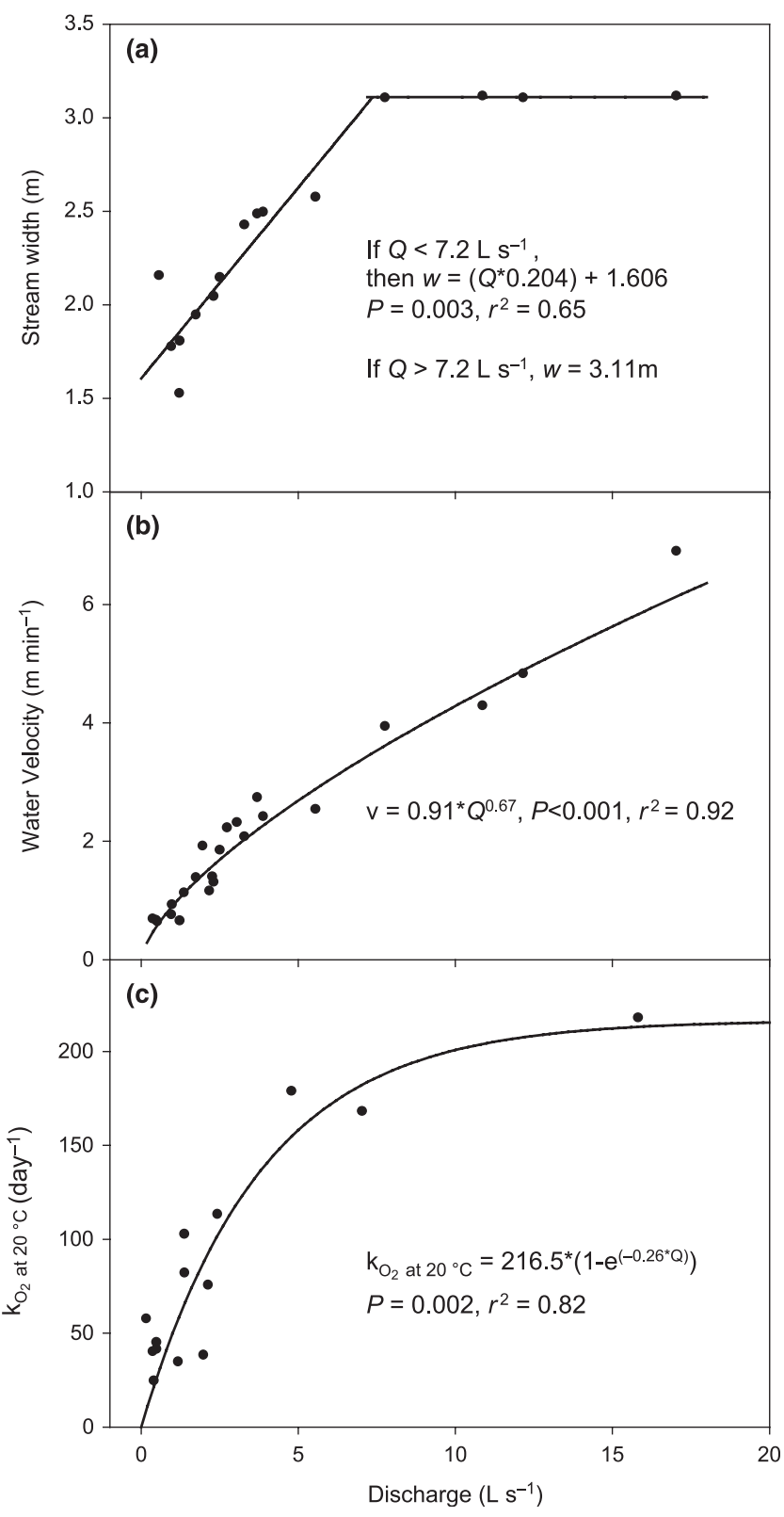

Fig. 2 Relationship between stream discharge $\left(\mathrm{L} \mathrm{s}^{-1}\right)$ and (a) stream width $(\mathrm{m}),(\mathrm{b})$ water velocity $\left(\mathrm{m} \mathrm{min}^{-1}\right)$ and $(\mathrm{c})$ the gas exchange rate of oxygen at $20^{\circ} \mathrm{C}\left(k_{\mathrm{O}_{2}}\right.$ at $\left.20^{\circ} \mathrm{C}\right)$ in Shepherd Creek.

lation, the two-station reach composed $19-40 \%$ of the reach affecting the downstream sonde, and there was no overlap between the two-station reach and the reach affecting the sonde at the top of the two-station reach. Despite the spatial discontinuities inherent in the one- and two-station calculations, the methods agreed remarkably well (Spearman rank correlation, $P<0.001, \rho \geq 0.81$, Figure S1), suggesting the two-station reach supported rates of GPP and ER similar to the reach measured by the one-station method. When determining controls on stream metabolism, preference was always given to data 
derived from the two-station method, followed by the one-station down and, finally, by the one-station up.

Ecosystem metabolism estimates can be biased by inputs of poorly oxygenated ground water (Mccutchan, Lewis \& Saunders, 1998; Hall \& Tank, 2005); however, median groundwater inflow rates were equivalent to only $7 \%$ of the stream discharge (Table S1), and no groundwater correction was applied to the data. Similarly, spatial heterogeneity in stream ecosystems can also bias metabolism estimates (Reichert, Uehlinger \& Acuña, 2009;
Demars et al., 2011b). We assessed the importance of heterogeneity by comparing metabolic rates calculated as described previously, and according to Demars et al. (2011b), a new method that attempts to correct for spatial variability. The two methods agreed well (Figure S2), and all calculations were performed as described previously.

Gross primary production and ER ranged from 0.001 to 12.50 and -0.39 to $-12.96 \mathrm{~g} \mathrm{O}_{2} \mathrm{~m}^{-2}$ day $^{-1}$, respectively (Fig. 3a), and showed distinct seasonal trends. GPP was high during ice-free winter days and throughout the
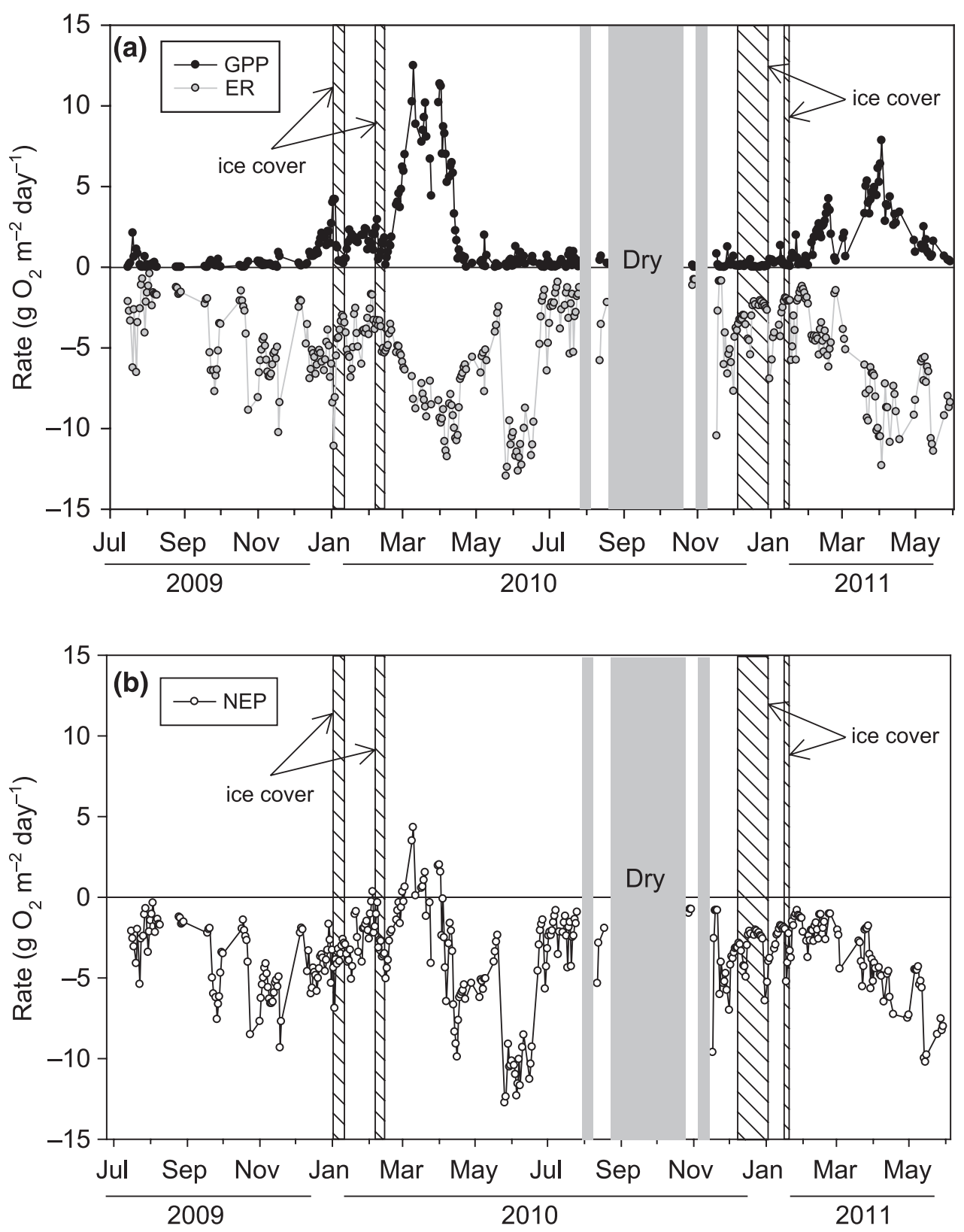

Fig. 3 Daily rates of (a) gross primary production (GPP: positive values, black line) and ecosystem respiration (ER: negative values, grey line) and (b) net ecosystem production (NEP) measured in Shepherd Creek from 1 July 2009 to 31 May 2011. Vertical grey and hatched bars indicate periods of no flow and ice cover, respectively. 
Table 2 Photosynthesis-irradiance (P-I) parameters for Shepherd Creek when the model $r^{2}$ exceeded 0.80

\begin{tabular}{|c|c|c|c|c|}
\hline Date & $\begin{array}{l}P_{\max }\left(\mathrm{mg} \mathrm{O}_{2} \mathrm{~m}^{-2}\right. \\
\left.\min ^{-1}\right)^{*}\end{array}$ & $\begin{array}{l}\alpha\left(\mathrm{mg} \mathrm{O} \mathrm{O}_{2} \mathrm{~m}^{-2} \min ^{-1} /\right. \\
\left.\mu \mathrm{mol} \text { photon } \mathrm{m}^{-2} \mathrm{~min}^{-1}\right)^{+}\end{array}$ & $\begin{array}{l}I_{k}^{\ddagger}(\mu \mathrm{mol} \\
\left.\text { photon } \mathrm{m}^{-2} \mathrm{~min}^{-1}\right)\end{array}$ & $r^{2 \S}$ \\
\hline 29 October 2010 & 0.03 & 0.0003 & 97 & 0.84 \\
\hline 31 December 2010 & 1.3 & 0.0137 & 96 & 0.93 \\
\hline 23 January 2011 & 1.4 & 0.0144 & 99 & 0.85 \\
\hline 26 January 2011 & 1.0 & 0.0088 & 117 & 0.95 \\
\hline 30 January 2011 & 1.5 & 0.0153 & 101 & 0.96 \\
\hline 31 January 2011 & 1.4 & 0.0182 & 74 & 0.98 \\
\hline 4 February 2011 & 3.2 & 0.0351 & 91 & 0.96 \\
\hline 5 February 2011 & 2.8 & 0.0332 & 84 & 0.94 \\
\hline 6 February 2011 & 4.9 & 0.0539 & 91 & 0.97 \\
\hline 7 February 2011 & 5.2 & 0.0639 & 82 & 0.96 \\
\hline 11 February 2011 & 5.1 & 0.0248 & 206 & 0.93 \\
\hline 12 February 2011 & 3.9 & 0.0279 & 140 & 0.95 \\
\hline 13 February 2011 & 5.6 & 0.0416 & 134 & 0.93 \\
\hline 14 February 2011 & 6.7 & 0.0580 & 115 & 0.98 \\
\hline 16 February 2011 & 7.7 & 0.0565 & 137 & 0.96 \\
\hline 17 February 2011 & 9.4 & 0.0614 & 153 & 0.98 \\
\hline 18 February 2011 & 10.1 & 0.0501 & 202 & 0.94 \\
\hline 19 February 2011 & 7.7 & 0.0425 & 181 & 0.93 \\
\hline 20 February 2011 & 5.9 & 0.0596 & 98 & 0.95 \\
\hline 23 February 2011 & 1.3 & 0.0110 & 115 & 0.96 \\
\hline 24 February 2011 & 1.2 & 0.0148 & 81 & 0.96 \\
\hline 2 March 2011 & 3.9 & 0.0195 & 202 & 0.88 \\
\hline 26 March 2011 & 8.8 & 0.0569 & 155 & 0.90 \\
\hline 27 March 2011 & 8.2 & 0.0806 & 102 & 0.88 \\
\hline 28 March 2011 & 9.0 & 0.0635 & 141 & 0.87 \\
\hline 29 March 2011 & 7.9 & 0.0636 & 124 & 0.85 \\
\hline 30 March 2011 & 9.6 & 0.0764 & 125 & 0.95 \\
\hline 31 March 2011 & 10.8 & 0.0632 & 172 & 0.94 \\
\hline 1 April 2011 & 9.8 & 0.0907 & 108 & 0.83 \\
\hline 2 April 2011 & 11.8 & 0.0924 & 128 & 0.94 \\
\hline 3 April 2011 & 14.9 & 0.0788 & 189 & 0.92 \\
\hline 6 April 2011 & 5.8 & 0.0262 & 221 & 0.95 \\
\hline 7 April 2011 & 7.9 & 0.0376 & 210 & 0.91 \\
\hline 8 April 2011 & 9.5 & 0.0399 & 239 & 0.94 \\
\hline 10 April 2011 & 9.4 & 0.0399 & 235 & 0.96 \\
\hline 14 April 2011 & 7.0 & 0.0358 & 195 & 0.93 \\
\hline 15 April 2011 & 8.0 & 0.0427 & 187 & 0.94 \\
\hline 18 April 2011 & 7.6 & 0.0391 & 194 & 0.92 \\
\hline 30 April 2011 & 3.6 & 0.0260 & 139 & 0.92 \\
\hline
\end{tabular}

${ }^{*} P_{\max }$ is the maximum photosynthesis rate.

${ }^{+} \alpha$ is the initial slope of the P-I curve.

${ }^{\ddagger} I_{k}$ is the irradiance level at which photosaturation begins.

$\S_{r}^{2}$ is the coefficient of determination for the model. 
spring, but dropped rapidly when the riparian canopy developed and reduced light levels. ER showed distinct peaks in the winter and spring that largely mirrored patterns in GPP, although ER exhibited greater day-to-day variation than GPP. ER exceeded GPP during all but 13 days during the 2010 algal bloom (Fig. 3b). Consequently, NEP was negative (i.e. the stream was heterotrophic) during most of the study period.

Interannual patterns in GPP were also evident, particularly during the winter and spring algal blooms of 2010 and 2011 (i.e. February-May). Peak GPP rates of c. $10 \mathrm{~g} \mathrm{O}_{2} \mathrm{~m}^{-2}$ day $^{-1}$ were maintained for nearly 2 months during the winter/spring of 2010, a period of relatively stable flow, while GPP peaked at only c. $5 \mathrm{~g} \mathrm{O}_{2} \mathrm{~m}^{-2}$ day $^{-1}$ during the same time period in 2011. Integrated GPP between 1 January and 15 May of 2011 was c. $40 \%$ lower than the same time period in 2010 (290 and $460 \mathrm{~g} \mathrm{O}_{2} \mathrm{~m}^{-2}$, respectively).

The two-parameter photosynthesis-irradiance curve fitted the instantaneous GPP and PAR data satisfactorily (e.g. $\left.r^{2}>0.80, P<0.001\right)$ on 57 of 174 days for which we had data. In general, the model fit the data well when GPP exceeded c. $1.5 \mathrm{~g} \mathrm{O}_{2} \mathrm{~m}^{-2}$ day $^{-1}$, which occurred exclusively during the winter and spring. All P-Icurves exhibited clear photosaturation at irradiance values $\left(I_{k}\right)$ between 74 and $266 \mu \mathrm{mol} \mathrm{m}{ }^{-2} \min ^{-1}\left(\right.$ mean $\left.I_{k}=143 \mu \mathrm{mol} \mathrm{m}^{-2} \mathrm{~min}^{-1}\right)$. Irradiance values at the onset of photosaturation tended to increase throughout the winter and spring algal bloom and were positively related to daily PAR $\left(r^{2}=0.34, P<0.001\right.$; Table 2). The average maximum photosynthesis rate, $P_{\max }$ was $6.0 \mathrm{mg} \mathrm{O}_{2} \mathrm{~m}^{-2} \mathrm{~min}^{-1}$ (range: 0.03-14.9) and was also positively related to daily PAR $\left(r^{2}=0.24, P<0.001\right)$. The initial slope of the P-I curve, $\alpha$, ranged from 0.0003 to 0.09 $\left(\mathrm{mg} \mathrm{O}_{2} \mathrm{~m}^{-2} \mathrm{~min}^{-1}\right) /\left(\mu \mathrm{mol}\right.$ photon $\left.\mathrm{m}^{-2} \mathrm{~min}^{-1}\right)$ and was strongly correlated with $P_{\max }\left(r^{2}=0.66, P<0.001\right)$, but was unrelated to daily PAR or $I_{k}(P>0.16)$.

On several dates, a strong counterclockwise temporal hysteresis was observed in the P-I curve (Fig. 4a) where GPP was greater in the afternoon than the morning at similar irradiance values. Water temperature often exhibited a similar hysteresis pattern (Fig. 4b). On days when the water temperature hysteresis exceeded $2.3^{\circ} \mathrm{C}$, the P-I always exhibited counterclockwise hysteresis (twodimensional Kolmogorov-Smirnov test, $P<0.001$ ), and the strength of the hysteresis effect followed that of the water temperature hysteresis (Fig. 4c).

\section{Controls on GPP and ER}

Quantile regression revealed that GPP was correlated with daily PAR (Fig. 5) but that the strength of the
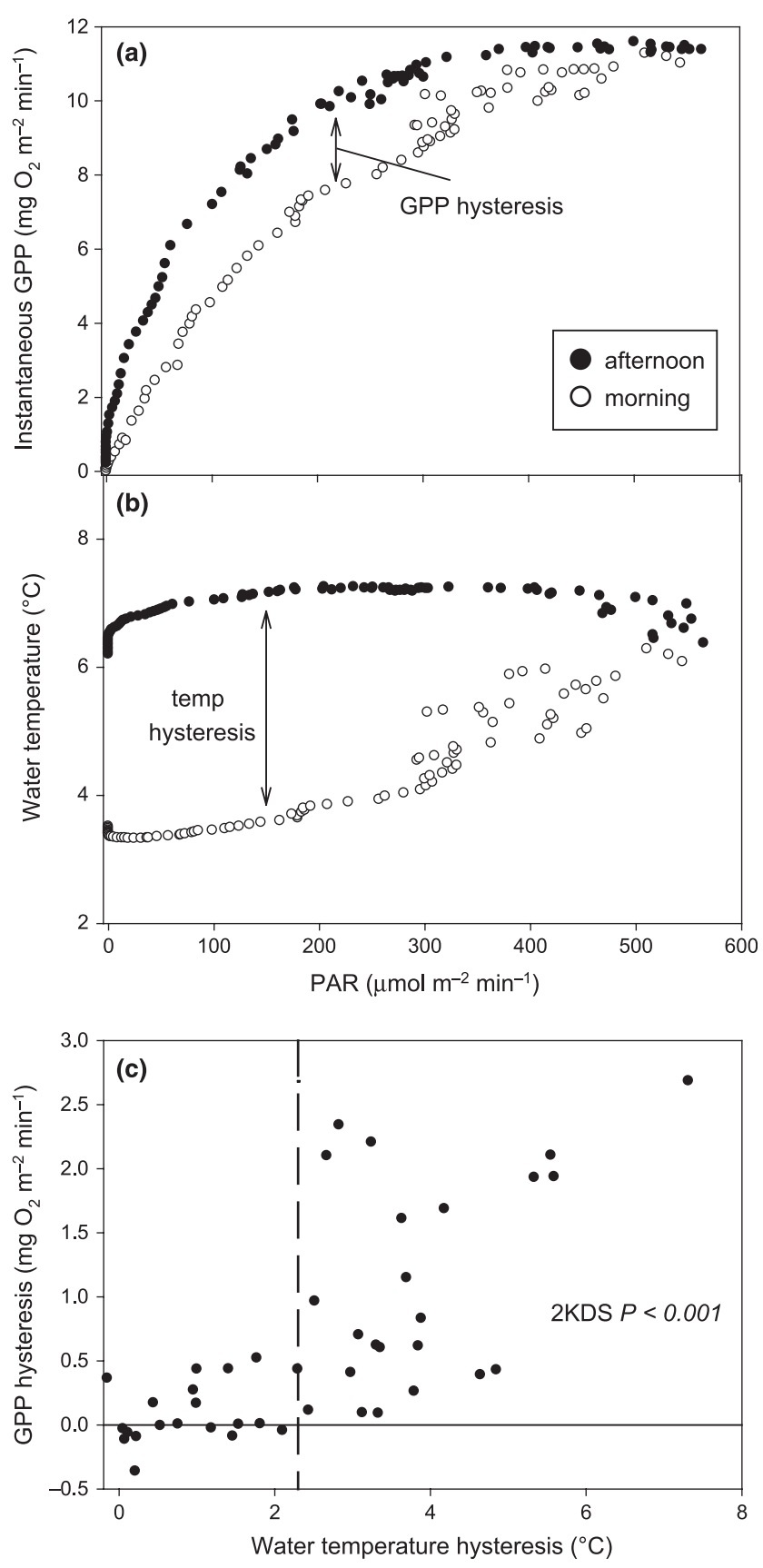

Fig. 4 (a) Instantaneous gross primary production (GPP) and (b) water temperature plotted against photosynthetically active radiation (PAR) on 31 March 2011. Filled and open circles represent afternoon and morning hours, respectively. Both panels exhibit counterclockwise hysteresis. (c) Degree of GPP hysteresis versus water temperature hysteresis for all days when hysteresis was present. Vertical dashed line represents a significant water temperature threshold, determined with a two-dimensional Kolmogorov-Smirnov test (2KDS), above which GPP hysteresis was consistently observed.

relationship (i.e. the slope of the regression line) increased from the lowest to highest quantile of the data. For example, the slope of the 95th, 50th and 5th conditional 


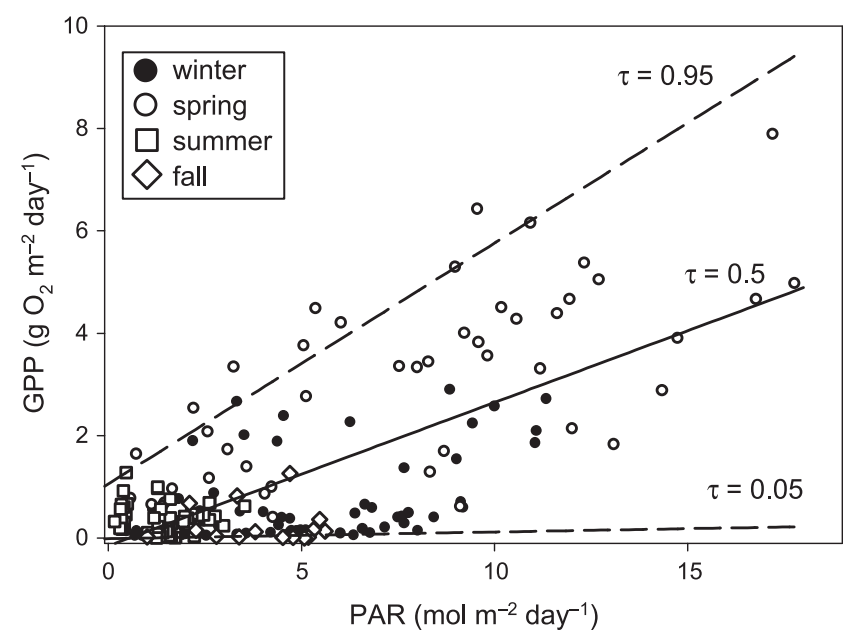

Fig. 5 Relationship between daily gross primary production (GPP) and photosynthetically active radiation (PAR). Symbols correspond to season (see legend). The upper and lower dashed lines correspond to the 95th and 5th quantile regression, respectively. The middle solid line represents a regression on the 50th quantile of the data distribution.

quantile regression lines was $0.47,0.21$ and 0.01 , respectively (Fig. 5). This result suggests that the response of GPP to daily PAR is conditional upon other factors. An analysis of covariance indicated that the presence or absence of snow cover was one seasonal factor that modified the GPP-PAR relationship $(P<0.001)$.

The best generalised least squares model for GPP included an autoregressive correlation structure and a variance structure that accounted for the differential spread in model residuals across seasons. The factors retained in the best model were water temperature $(P=0.32)$, daily PAR $(P=0.03)$ and a temperature-PAR interaction $(P=0.013$; Table 3$)$. This model indicates that water temperature did not directly influence GPP but that the response of GPP to PAR is greater at higher water

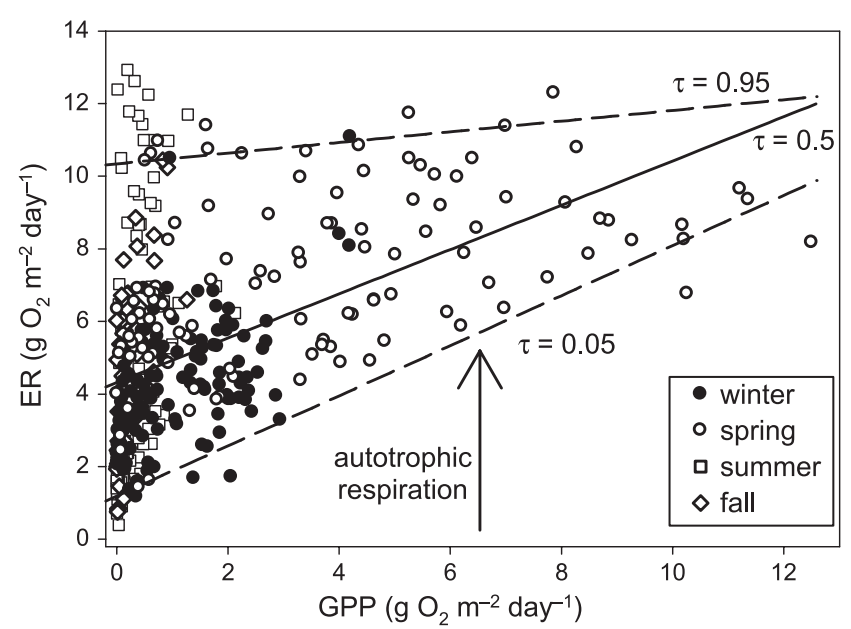

Fig. 6 Relationship between daily ecosystem respiration (ER, represented as positive values) and gross primary production (GPP). Symbols correspond to season (see legend). The upper and lower dashed lines correspond to the 95th and 5th quantile regression, respectively. The middle solid line represents a regression on the 50th quantile of the data distribution.

temperatures. This relationship is likely to contribute to the variation seen in the quantile regression results. We found no relationship between GPP and DIN, although GPP was negatively correlated with SRP $(P<0.001$, $\left.r^{2}=0.36\right)$ due to the co-occurrence of high GPP and low SRP during the winter/spring of 2010.

Quantile regression revealed that the lower quantiles of the ER-GPP distribution were related, but the relationship weakened at the higher quantiles of the distribution (Fig. 6, ER displayed as positive values). The best generalised least squares model for ER included an autoregressive correlation structure and a variance structure that accounted for the differential spread in model residuals across seasons. The factors retained in the best model were water temperature $(P<0.001)$ and GPP

Table 3 Gross primary production (GPP) and ecosystem respiration (ER) summaries for final models selected using the stepwise Akaike information criterion. Model covariates are water temperature (Temperature, ${ }^{\circ} \mathrm{C}$ ) and daily integrated photosynthetically active radiation $(\mathrm{PAR}$, $\mathrm{mol} \mathrm{m}{ }^{-2}$ day $\left.^{-1}\right)$. Models contained an autoregressive correlation structure and a variance structure that accounted for the differential spread in model residuals across seasons

\begin{tabular}{|c|c|c|c|c|c|}
\hline Variable & Estimate & SE & $t$ & $P$ & Correlation $^{+}$ \\
\hline \multicolumn{6}{|l|}{ GPP model summary } \\
\hline Temperature & -0.018 & 0.018 & -0.99 & 0.33 & \multirow[t]{2}{*}{0.75} \\
\hline Temperature*Daily PAR & 0.007 & 0.003 & 2.51 & 0.013 & \\
\hline \multicolumn{6}{|l|}{ ER model summary } \\
\hline
\end{tabular}

${ }^{\dagger}$ Correlation is the Pearson's product moment correlation coefficient of the predicted and observed values.

Published 2013. This article is a U.S. Government work and is in the public domain in the USA. Freshwater Biology, 58, 918-937 
930 J. J. Beaulieu et al.

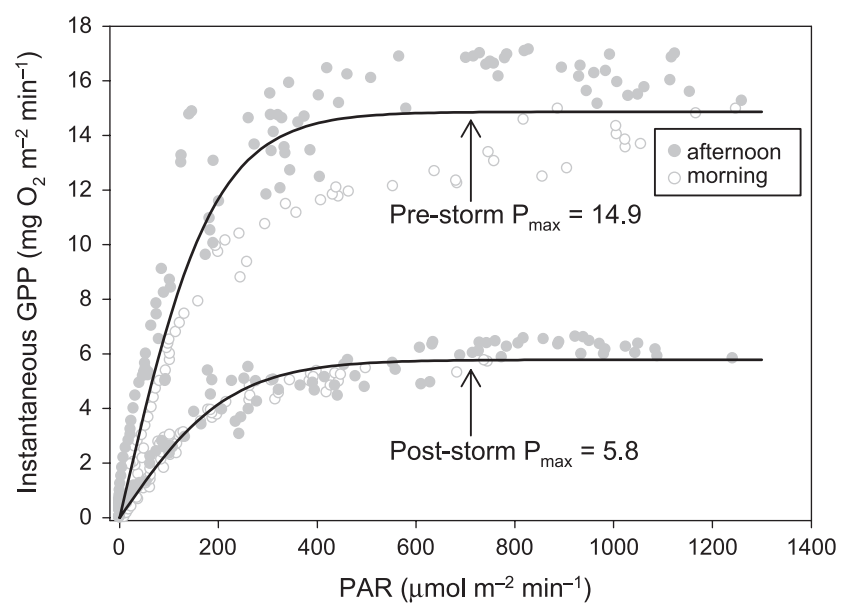

Fig. 7 Photosynthesis-irradiance curves on 3 April and 6 April 2011. Storm flows exceeding $1400 \mathrm{~L} \mathrm{~s}^{-1}$ occurred during the intervening 2 days. Pre- and post-storm maximum photosysnthesis rates $\left(P_{\max }\right)$ are indicated. Open and filled circles represent morning and afternoon hours, respectively. The pre-storm data exhibit counterclockwise hysteresis. No hysteresis is apparent in the post-storm data.

$(P<0.001)$, but the interaction between GPP and water temperature was not significant $(P=0.23$; Table 3$)$. No water chemistry measures showed meaningful relationships with ER.

We ran a reduced model using ER and other environmental variables collected on the 20 days when transient storage was measured. This model indicates that ER was unrelated to $A_{\mathrm{s}} / A$ or $F_{\text {med }}^{200}$ ( $P=0.85, P=0.78$, respectively), but that ER was positively related to discharge (Table $1 ; r^{2}=0.35, P<0.001$ ) and to the storage zone exchange flux, $q_{\mathrm{s}}$ (Table $1, r^{2}=0.36, P=0.01$ ).

We found no consistent effect of storm pulses on GPP or ER across the year; however, there were clear examples of GPP suppression following storm pulses in the spring. For example, $P_{\max }$ was suppressed $61 \%$ following a $1500 \mathrm{~L} \mathrm{~s}^{-1}$ storm pulse in early April 2011 (Fig. 7).

\section{Discussion}

We found that a combination of light availability, water temperature, desiccation and disturbance from storm flows controlled daily, seasonal and interannual variability in ecosystem metabolism. At the seasonal scale, patterns in stream metabolism were largely determined by highly predictable patterns in water temperature and light availability. These seasonal patterns were modified at the daily scale by unpredictable and less extreme changes in light and temperature associated with transient weather systems. Seasonal patterns were further modified by stochastic storm pulses that tended to depress GPP temporarily, particularly during the spring and winter when algae blooms dominated the well-lit channel. Finally, desiccation of the stream during dry summers temporarily converts the stream to a terrestrial ecosystem with no aquatic metabolism. However, GPP showed remarkable resilience to desiccation and stream periphyton began fixing carbon at low rates within $24 \mathrm{~h}$ of rewetting.

\section{Controls on GPP}

Gross primary production was characterised by a strong pulse during the winter and spring when the riparian canopy was open, followed by low rates during the summer and autumn after the riparian canopy closed. Therefore, the phenology of riparian zone vegetation drove this temporal pattern in GPP by controlling light availability at the stream surface. The riparian zone overstorey was composed of native deciduous trees, but light availability in the stream was controlled by a dense understory of non-native honeysuckle. (L. maackii), a deciduous shrub that extends the low-light period in the stream by developing leaves earlier in the season and holding them later than native vegetation (Shustack, Rodewald \& Waite, 2009). It is likely that L. maackii suppresses annual GPP in affected streams by shortening the duration of the spring algal bloom and extending the low-light conditions that maintain low GPP from May to December.

Quantile regression revealed that the relationship between daily GPP and PAR varied as a function of the quantile of the data examined, suggesting the relationship was conditional upon other factors. One such factor is the presence or absence of ice cover on the stream which can greatly reduce light transmission to the benthos, thereby suppressing GPP (Wetzel, 2001). This was particularly evident in January 2010, when GPP was strongly suppressed for 2 weeks during ice cover. The same pattern was evident to a lesser extent during the three additional periods of ice cover. We can find no reports of wholestream metabolism measurements taken under ice cover, probably due to the logistical difficulties of making the measurements, but we suspect that GPP suppression during ice cover is a widespread phenomenon in streams in the temperate zone and higher latitudes.

Water temperature also modified the relationship between GPP and PAR. We found that water temperature and PAR interacted synergistically, such that higher water temperature enhanced the response of GPP to PAR. This suggests the highest GPP rates should occur during warm spring days, prior to leaf-out. It is well established that temperature directly affects photosynthesis at the cellular level through its control on enzyme 
reaction rates and indirectly by inducing changes in enzyme and chlorophyll a concentrations (Denicola, 1996), although few studies have demonstrated this relationship at the ecosystem scale, possibly due to the confounding effects of other variables. For example, we found no direct relationship between water temperature and GPP, probably because the relationship was confounded by light availability. Periods of highest water temperature occurred during the summer, when light availability was relatively low. Similarly, studies of stream metabolism across large spatial gradients (Mulholland et al., 2001; Bernot et al., 2010) or through time in small-temperate streams (Acuña et al., 2004; Roberts et al., 2007) have failed to detect a temperature effect. Several studies of metabolism in large, unshaded streams have shown a positive relationship between GPP and water temperature (Uehlinger, 2006; Hunt et al., 2011); however, water temperature and light covaried in these studies making it difficult to ascertain the causal factor. In a welldesigned 'natural experiment', Demars et al. (2011b) found that GPP was strongly related to water temperature across 13 co-located streams spanning a $20{ }^{\circ} \mathrm{C}$ temperature gradient due to the influence of geothermal springs. Our findings, in combination with those of Demars et al. (2011b), are among the first to demonstrate that water temperature can influence GPP at the ecosystem scale. Reconciling the temperature dependence of aquatic photosynthesis from cells to ecosystems remains an important challenge in refining the metabolic theory of ecology (Brown et al., 2004).

The relationship between GPP and light is also influenced by time since the last storm. We found that spring storms substantially suppressed GPP, consistent with reports from rivers in Switzerland (Uehlinger \& Naegeli, 1998; Uehlinger, 2006) and a small stream in the United States (Roberts et al., 2007), presumably because attached periphyton were exported from the reach or disrupted by abrasion from suspended sediment and bedload movement. Future climate change scenarios predict that the frequency of bed-moving flows in headwater streams will increase, suggesting that GPP in headwater streams will become increasingly regulated by storm flows.

The importance of light in controlling GPP was seen not only at the daily scale, but also in the instantaneous GPP measurements taken at 5-min intervals during the daylight hours. We explored this relationship using photosynthesis-irradiance (P-I) curves, which model instantaneous GPP as a function of light. We found that instantaneous GPP was strongly correlated with light when the latter was low, but began to saturate at irradiances between 74 and $266 \mu \mathrm{mol} \mathrm{m}{ }^{-2} \mathrm{~min}^{-1}$, with complete saturation achieved shortly thereafter. These data provide clear evidence that instantaneous GPP was light saturated during most of the spring and winter. Photosaturation of stream biofilms has been well established using laboratory incubations of stream periphyton (Hill \& Boston, 1991; Hill, Mulholland \& Marzolf, 2001; Hill \& Dimick, 2002) and whole-system measurements in experimental streams, but mixed results have been reported at the ecosystem scale (Edwards \& Owens, 1962; Hornberger, Kelly \& Eller, 1976; Mulholland et al., 2001; Acuña et al., 2004). Several factors may determine whether photosaturation occurs in a stream; for example, unshaded streams may support high-light-adapted periphyton with high $I_{k}$ values (Hill \& Boston, 1991). Mulholland et al. (2001) reported ecosystem scale P-I curves for six streams distributed across the United States; all but Sycamore Creek, an unshaded desert stream, showed evidence of photosaturation, possibly because the substantial periphyton community in Sycamore Creek (178 $\mathrm{g} \mathrm{AFDM} \mathrm{m}^{-2}$ ) was adapted to high light and had an $I_{k}$ value greater than the measured light intensity. The $I_{k}$ value tended to increase during the winter and spring of this study and was correlated with daily PAR $\left(r^{2}=0.34\right.$, $P<0.001$ ), suggesting the periphyton became increasingly light adapted throughout the winter/spring GPP pulse.

We saw consistent evidence of photosaturation within a day during the winter/spring GPP pulse, but no evidence of photosaturation at the per day scale. While many researchers have found correlations between daily GPP and PAR (Young \& Huryn, 1999; Mulholland et al., 2001; Roberts et al., 2007; Bernot et al., 2010; Hunt et al., 2011), only one has reported photosaturation at the per day scale (Bott et al., 2006). Several explanations for a lack of photosaturation at the daily scale have been suggested including long-term adaption to high light (Mulholland et al., 2001) and differences in the number of light hours within a day (Roberts et al., 2007). Daily PAR integrates both PAR intensity and the duration of exposure; therefore, longer days will support large daily PAR values, even if instantaneous GPP was photosaturated during much of day. In this study, day length increased throughout the winter/spring GPP pulse, and the $I_{k}$ data suggest the periphyton community was becoming increasingly light adapted during the same period. We conclude that both high-light adaptation by the periphyton community and differences in day length resulted in the lack of photosaturation in daily GPP rates.

The P-I curves often exhibited a strong temporal hysteresis, where GPP was greater in the afternoon than the morning under similar PAR levels, a pattern referred to here as 'counterclockwise hysteresis'. Counterclockwise 
932 J. J. Beaulieu et al.

hysteresis has been reported during high-light conditions across a broad range of stream ecosystems including a third-order Mediterranean stream (Acuña et al., 2004), a highly productive desert stream (Mulholland et al., 2001), a high-light prairie stream (Mulholland et al., 2001) and artificial streams (Gulliver \& Stefan, 1984). Mulholland et al. (2001) suggested counterclockwise hysteresis may have resulted from a delay in oxygen diffusion from within algal mats to the overlying water, while Acuña et al. (2004) suggested afternoon GPP may be stimulated by elevated water temperatures. Consistent with Acuña et al. (2004), we found that water temperature also exhibited up to $7{ }^{\circ} \mathrm{C}$ of counterclockwise hysteresis, and the degree of hysteresis in the P-I curve was significantly related to the degree of temperature hysteresis. Counterclockwise hysteresis was always observed in the P-I curve when the temperature hysteresis exceeded $2.2^{\circ} \mathrm{C}$, suggesting that increased water temperature in the afternoon stimulates GPP. This relationship corroborates our finding that water temperature influences GPP at the daily scale and is consistent with the well-documented positive relationship between temperature and photosynthesis at the cellular level (Denicola, 1996).

The role of stream water nutrient concentrations in controlling daily GPP in streams is not straightforward. Several investigators have reported positive relationships between $\mathrm{NO}_{3}^{-}$or SRP and GPP (Peterson et al., 1985; Mulholland et al., 2001; Bernot et al., 2010), while others have reported negative relationships (Roberts et al., 2007), and yet others have found no relationship (Young \& Huryn, 1999; Acuña et al., 2004; Izagirre et al., 2008). We found no relationship between GPP and DIN, although GPP was negatively correlated with SRP due to the cooccurrence of high GPP and low SRP during the winter/spring of 2010. Roberts et al. (2007) demonstrated that high rates of autotrophic SRP uptake during the winter/spring GPP pulse can result in decreased stream water SRP concentrations. In our study, however, the DIN/SRP molar ratios were generally below the Redfield ratio of 16 during the GPP pulse (80th percentile $=15.5$ ), suggesting GPP was not P limited and the low winter/spring SRP concentration was not likely to be a result of enhanced autotrophic P assimilation. Thus, it appears that light, rather than nutrients, was the primary limiting factor for GPP in this high-nutrient suburban stream.

Despite high nutrients and light during the winter/spring GPP pulse, the maximum daily GPP rate of $12.5 \mathrm{~g} \mathrm{O}_{2} \mathrm{~m}^{-2}$ day $^{-1}$ was similar to, or less than, that observed in much lower nutrient systems including an undeveloped forested stream ( $\max =10.8 \mathrm{~g} \mathrm{O}_{2} \mathrm{~m}^{-2}$ day $^{-1}$; Roberts et al., 2007), two intermontane streams (stream one $\max =13.6$, stream two max $=16.2 \mathrm{~g} \mathrm{O}_{2} \mathrm{~m}^{-2}$ day $^{-1}$; Bernot et al., 2010) and an oligotrophic unshaded stream in Iceland $(\max =28$ $\mathrm{g} \mathrm{O}_{2} \mathrm{~m}^{-2}$ day $^{-1}$; Demars et al., 2011b). The apparent lack of a nutrient control on GPP across a range of high-light streams suggests autotrophs can compensate for low nutrient availability, perhaps via rapid and tightly coupled nutrient cycling rates (Demars et al., 2011b). Given that GPP was not nutrient limited and the P-I curve showed clear photosaturation during the winter-spring algal bloom, maximum daily GPP was probably limited by the physiological capacity of the periphyton community to harness the available light for photosynthesis. The light harvesting capacity of periphyton assemblages is controlled by the taxonomic composition and abundance of the community, which in turn are controlled by biotic (e.g. grazing) and abiotic factors (e.g. scour; Hill, Ryon \& Schilling, 1995).

\section{Controls on ER}

The most prominent temporal pattern in ER was the winter/spring peak, which largely mirrored the concurrent GPP pulse. This may reflect a strong contribution of autotrophic respiration (AR) to ER. ER did not, however, show a peak during the autumn leaf fall (when allochthonous carbon inputs are expected to be high). This may be because the channel of this suburban stream was entrenched, geomorphologically simple and contained few in-stream structures to retain particulate allochthonous carbon inputs (Hoover, Richardson \& Yonemitsu, 2006). Furthermore, frequent spates during the autumn tended to scour leaves from the stream channel, thereby exporting material that would otherwise have supported heterotrophic respiration.

The best predictor of ER was GPP; however, the relationship was not straightforward, as demonstrated by the quantile regression results. At the lowest quantile of the distribution (i.e. $\tau=0.05$ ), ER was well-predicted by GPP. This regression line reflects the minimum amount of ER that was observed at any given value of GPP and may represent the contribution of AR to ER (Hall and Beaulieu, in press). The slope of the line is $0.69 \pm 0.15$ (95\% CI), suggesting that autotrophs respire up to $69 \%$ of fixed carbon. At increasing quantiles of the ER-GPP relationship, there are regions where either heterotrophic or autotrophic respiration appears to be the dominant component of ER. For example, at low GPP and high ER rates along the 95th quantile regression line, heterotrophic respiration is likely to dominate ER. Alternatively, where high ER and GPP co-occur along the 95th quantile regression line, AR may be the more important component of ER. The relative importance of $A R$ and $H R$ to ER is 
likely determined by a number of factors including light, organic matter standing stocks, magnitude of hyporheic zone respiration and temperature.

We found that ER was positively related to temperature (Table 2), which is consistent with metabolic theory (Allen, Gillooly \& Brown, 2005) and two inter-biome comparisons of stream metabolism (Bott et al., 1985; Sinsabaugh, 1997). However, the temperature dependence of respiration can be confounded by many variables, including carbon and nutrient availability, and many studies of metabolism in temperate streams have found either no relationship, or a weak or negative relationship, between ER and temperature (Young \& Huryn, 1999; Mulholland et al., 2001; Acuña et al., 2004; Roberts et al., 2007). The lack of a consistent temperature effect across studies may be because maximum ER rates often co-occur with leaf litter inputs during the autumn when water temperature is relatively low. While Shepherd Creek received substantial allochthonous carbon subsidies during the autumn, these inputs probably had a short residence time due to frequent scouring spates and the lack of in-stream retention. This effectively eliminated the autumn ER pulse reported in other temperate streams and may be another symptom of the urban stream syndrome (Walsh et al., 2005).

At the site level, numerous factors may confound the functional relationship between respiration and temperature. This relationship becomes clear, however, using meta analysis techniques or comparative surveys in model systems (Demars et al., 2011b). Yvon-Durocher et al. (2012) used a meta analysis to demonstrate that the sensitivity of respiration to seasonal changes in temperature is similar across a diverse collection of terrestrial and aquatic ecosystems, including streams and rivers. This meta survey, which was based on the largest database of respiratory measurements yet compiled, provides strong evidence that the temperature dependence of respiration propagates from the cellular to the ecosystem level in flowing waters, but statistically isolating the effects of temperature from other variables in individual studies remains a challenge.

We found no significant relationship between ER and the size of the transient storage zone $\left(A_{\mathrm{s}} / A\right)$ or the median travel time associated with transient storage $\left(F_{\text {med }}^{200}\right)$. Previous studies have shown inconsistent relationships between ER and hydrology, with some showing a positive relationship with size of the transient storage zone (Fellows et al., 2001; Mulholland et al., 2001; Demars et al., 2011a), and some showing no relationship (Martí et al., 2009; Bernot et al., 2010). We did, however, find a positive relationship between discharge and ER, and we also found a positive relationship between ER and the exchange flux with the transient storage zone $\left(q_{\mathrm{s}}\right)$. Up- and down-welling has been shown to be an important driver of biological activity in the hyporheic zone (Argerich et al., 2011), and a modelling approach identified transient storage connectivity as an important factor for rapid rates of biological activity (Stewart et al., 2011). Overall, these relationships may indicate that greater hyporheic exchange during high flows stimulates heterotrophic metabolism by replenishing porewater dissolved organic matter and nutrients that may otherwise become limiting. This interpretation assumes the measured transient storage was hyporheic, rather than surficial (e.g. pools, channel edges), which cannot be confirmed with our data.

Numerous studies have demonstrated a link between microbial respiration and DOC availability in lotic systems (Uehlinger, König \& Reichert, 2000; Baker \& Vervier, 2004; Uehlinger, 2006), and this link might be particularly strong in urban streams that can receive inputs of highly labile DOC from leaking sewers, failing septic tanks, and undocumented connections between septic and stormwater systems and residential lawns (Paul \& Meyer, 2001; Newcomer et al., 2012). Persistently high Escherichia coli concentrations in Shepherd Creek (annual average: $408 \mathrm{CFU} 100 \mathrm{~mL}^{-1}$, unpubl. data) suggest that septic waste may be entering the stream, although we found no relationship between DOC and ER. One explanation for this pattern is that ER may be supported by a relatively small, but highly labile fraction of the bulk DOC pool derived from anthropogenic sources (Mayorga et al., 2005). For example, in a 15 -year study of metabolism in a Swiss river, Uehlinger (2006) attributed a 50\% reduction in ER to a threefold reduction in organic loading to the river from wastewater treatment works, despite constant bulk DOC concentrations in the river during this period. The stimulatory effects of small quantities of highly labile DOC on ER may also be responsible for the spike in ER observed in June 2010. This period of raised ER was not accompanied by increased GPP and cannot be explained by bulk DOC concentrations, which ranged from 3.8 to $6.2 \mathrm{mg} \mathrm{L}^{-1}$ during this period, but it may be linked with temporary BOD loading associated with illegal inputs or maintenance activities that temporarily disrupted the sanitary sewer network (Stutter, Demars \& Langan, 2010).

\section{Interannual patterns in metabolism}

While intra-annual patterns in GPP were largely controlled by predictable temporal variations in light and temperature, interannual variation was largely controlled by less predictable factors including the frequency of storm flows and duration of desiccation. Storm flows clearly depressed 
$934 J$. J. Beaulieu et al.

GPP during winter and spring and were much more frequent during the 2011 than 2010 GPP pulse. Consequently, peak daily GPP in $2011\left(7.86 \mathrm{~g} \mathrm{O}_{2} \mathrm{~m}^{-2}\right.$ day $\left.^{-1}\right)$ was only $60 \%$ of that in $2010\left(12.50 \mathrm{~g} \mathrm{O}_{2} \mathrm{~m}^{-2}\right.$ day $\left.^{-1}\right)$. Similarly, when integrated across the winter/spring pulse, GPP in $2011\left(279 \mathrm{~g} \mathrm{O}_{2} \mathrm{~m}^{-2}\right)$ was only $60 \%$ of that in 2010 $\left(476 \mathrm{~g} \mathrm{O}_{2} \mathrm{~m}^{-2}\right)$. While temporary reductions in GPP following storm flows appears to be a common feature of streams (Roberts et al., 2007) and rivers (Uehlinger \& Naegeli, 1998; Uehlinger, 2006), urban and suburban streams are likely to experience more frequent and intense storm flows than streams draining undeveloped basins (Walsh et al., 2005). This may be compounded by climate change which is predicted to produce fewer, but more intense precipitation events.

Impervious surfaces associated with urbanisation not only increase peak flows, but also reduce groundwater recharge leading to more frequent periods of desiccation in intermittent streams (Walsh et al., 2005). During 2010, stream flow ceased from 28 July to 15 November, with the exception of two brief periods following rainfall (i.e. 9 and 5 days). During this dry period, the stream channel supported no aquatic metabolism, which contributed to the interannual variation observed in the 2 years of the study. Stream GPP exhibited remarkable resilience to this disturbance however, and a clear P-I curve was recorded in the stream within 3 days of rewetting, albeit with a low $P_{\max }$ value (Table 2, 29 October 2010). High resilience to desiccation has been reported for extreme environments like Antarctica (Hawes, Howard-Williams \& Vincent, 1992) but has not been well documented for more typical streams (cf. Dodds et al., 1996; Timoner et al., 2012), particularly at the ecosystem scale. Understanding how stream ecosystems recover from water loss should be a research priority given that increased urbanisation and climate change may increase the frequency and duration of desiccation in intermittent streams.

In conclusion, our continuous whole-ecosystem approach for measuring stream metabolism revealed that a combination of light availability, water temperature, desiccation and disturbance from storm flows controlled GPP and ER. Light availability at the stream bed was the most important determinant of stream metabolism at the daily and seasonal scale; however, the relationship between GPP and light was conditional upon other factors including water temperature, time since last storm and ice cover. ER was best predicted by a combination of GPP and water temperature.

This research illustrates the advantages of continuous monitoring for identifying the controls on ecosystem metabolism. Most investigations of ecosystem metabolism are performed under stable flow conditions during brief windows thought to represent the biologically important periods at the study sites (e.g. seasonal measurements). This approach is unlikely to capture short term, but ecologically important, events such as storm flows, ice cover and post-desiccation recovery. Furthermore, shortterm approaches are also unlikely to yield sufficient statistical power to identify subtle controls on ecosystem metabolism, such as the synergism between light and water temperature revealed in this work.

All factors shown here to influence stream metabolism have been affected by human activities, highlighting the potential vulnerability of stream ecosystem function to anthropogenic disturbance. Predicting the net effect of these simultaneous perturbations on stream ecosystem function should be a research priority as we move into an uncertain climatological future with a growing urban footprint. Efforts to develop predictive metabolism models are underway and current models include the effects of water temperature and canopy cover (Bunn, Davies \& Mosisch, 1999; Marcarelli, Van Kirk \& Baxter, 2010). Our research suggests that predictions may be improved if metabolism and hydrology are modelled as a linked hydroecological system. We anticipate rapid progress in this field as programmes such as the National Ecological Observatory Network facilitate the collection of continuous ecosystem metabolism and hydrological data at unprecedented spatial and temporal scales (Keller et al., 2008).

\section{Acknowledgments}

We thank Chris Nietch (US EPA) for analytical support and several private landowners for access to the study site. We acknowledge the United States Geological Survey for designing and maintaining the stream gauges. We are grateful to Drs. Robert O. Hall Jr., Laura Taylor-Johnson and Natalie Griffiths for their helpful discussions and to two anonymous reviewers for their comments and suggestions.

\section{References}

Acuña V., Giorgi A., Muñoz I., Uehlinger U. \& Sabater S. (2004) Flow extremes and benthic organic matter shape the metabolism of a headwater mediterranean stream. Freshwater Biology, 49, 960-971.

Akaike H. (1974) New look at statistical model identification. IEEE Transactions on Automatic Control, AC19, 716-723.

Allen A.P., Gillooly J.F. \& Brown J.H. (2005) Linking the global carbon cycle to individual metabolism. Functional Ecology, 19, 202-213. 
APHA (2005) Standard Methods for the Examination of Water and Wastewater. American Public Health Association, Washinton, DC.

Argerich A., Marti E., Sabater F. \& Ribot M. (2011) Temporal variation of hydrological exchange and hyporheic biogeochemistry in a headwater stream during autumn. Journal of the North American Benthological Society, 30, 635-652.

Baker M.A. \& Vervier P. (2004) Hydrological variability, organic matter supply and denitrification in the garonne river ecosystem. Freshwater Biology, 49, 181-190.

Bernot M.J., Sobota D.J., Hall R.O., Mulholland P.J., Dodds W.K., Webster J.R. et al. (2010) Inter-regional comparison of land-use effects on stream metabolism. Freshwater Biology, 55, 1874-1890.

Bott T.L., Brock J.T., Dunn C.S., Naiman R.J., Ovink R.W. \& Petersen R.C. (1985) Benthic community metabolism in four temperate stream systems: an inter-biome comparison and evaluation of the river continuum concept. Hydrobiologia, 123, 3-45.

Bott T.L., Newbold J.D. \& Arscott D.B. (2006) Ecosystem metabolism in piedmont streams: reach geomorphology modulates the influence of riparian vegetation. Ecosystems, 9, 398-421.

Brown J.H., Gillooly J.F., Allen A.P., Savage V.M. \& West G.B. (2004) Toward a metabolic theory of ecology. Ecology, 85, 1771-1789.

Bunn S.E., Davies P.M. \& Mosisch T.D. (1999) Ecosystem measures of river health and their response to riparian and catchment degradation. Freshwater Biology, 41, 333-345.

Cade B.S. \& Noon B.R. (2003) A gentle introduction to quantile regression for ecologists. Frontiers in Ecology and the Environment, 1, 412-420.

Chapra S.C. \& Di Toro D.M. (1991) Delta method for estimating primary production, respiration, and reaeration in streams. Journal of Environmental Engineering, 117, 640655.

Demars B.O.L., Manson J.R., Ólafsson J.S., Gíslason G.M. \& Friberg N. (2011a) Stream hydraulics and temperature determine the metabolism of geothermal Icelandic streams. Knowledge and Management of Aquatic Ecosystems, 402, DOI: $10.1051 / \mathrm{kmae} / 2011046$.

Demars B.O.L., Russell Manson J., Ólafsson J.S., Gíslason G.M., Gudmundsdóttir R., Woodward G. et al. (2011b) Temperature and the metabolic balance of streams. Freshwater Biology, 56, 1106-1121.

Denicola D.M. (1996) Periphyton response to temperature at different ecological levels. In: Algal Ecology. Freshwater Benthic Ecosystems (Eds R.J. Stevenson, M.L. Bothwell \& R.L. Lowe), pp. 149-181. Academic Press, San Diego, CA.

Dodds W.K., Hutson R.E., Eichem A.C., Evans M.A., Gudder D.A., Fritz K.M. et al. (1996) The relationship of floods, drying, flow and light to primary production and producer biomass in a prairie stream. Hydrobiologia, 333, 151-159.
Edwards R.W. \& Owens M. (1962) The effects of plants on river conditions IV. The oxygen balance of a chalk stream. Journal of Ecology, 50, 207-220.

Elmore H.L. \& West W.F. (1961) Effect of temperature on stream reaeration. Journal of the Sanitary Engineering Division. Proceedings of the American Society of Civil Engineering, 87, 59-71.

Fellows C.S., Valett H.M. \& Dahm C.N. (2001) Whole-stream metabolism in two montane streams: contribution of the hyporheic zone. Limnology and Oceanography, 46, 523531.

Genereux D.P. \& Hemond H.F. (1992) Determination of gasexchange rate constants for a small stream on Walker Branch watershed, Tennessee. Water Resources Research, 28, 2365-2374.

Gulliver J.S. \& Stefan H.G. (1984) Stream productivity analysis with DORM-III: productivity of experimental streams. Water Research, 18, 1589-1595.

Hall R.O. \& Tank J.L. (2005) Correcting whole-stream estimates of metabolism for groundwater input. Limnology and Oceanography: Methods, 3, 222-229.

Hall R.O. \& Beaulieu J.J. (in press) Estimating autotrophic respiration in streams using daily metabolism data. Freshwater Science, 32.

Harvey J.W. \& Wagner B.J. (2000) Quantifying hydrologic interactions between streams and their subsurface hyporheic zones. In: Streams and Groundwaters (Eds J.B. Jones \& P.J. Mulholland), pp. 3-44. Aquatic Ecology Series. Academic Press, San Diego, CA.

Hawes I., Howard-Williams C. \& Vincent W.F. (1992) Desiccation and recovery of Antarctic cyanobacterial mats. Polar Biology, 12, 587-594.

Herb W.R., Janke B., Mohseni O. \& Stefan H.G. (2008) Thermal pollution of streams by runoff from paved surfaces. Hydrological Processes, 22, 987-999.

Hill W.R. \& Boston H.L. (1991) Community development alters photosynthesis-irradiance relations in stream periphyton. Limnology and Oceanography, 36, 1375-1389.

Hill W.R. \& Dimick S.M. (2002) Effects of riparian leaf dynamics on periphyton photosynthesis and light utilisation efficiency. Freshwater Biology, 47, 1245-1256.

Hill W.R., Mulholland P.J. \& Marzolf E.R. (2001) Stream ecosystem responses to forest leaf emergence in spring. Ecology, 82, 2306-2319.

Hill W.R., Ryon M.G. \& Schilling E.M. (1995) Light limitation in a stream ecosystem-responses by primary producers and consumers. Ecology, 76, 1297-1309.

Hoover T.M., Richardson J.S. \& Yonemitsu N. (2006) Flowsubstrate interactions create and mediate leaf litter resource patches in streams. Freshwater Biology, 51, 435447.

Hornberger G.M., Kelly M.G. \& Eller R.M. (1976) The relationship between light and photosynthetic rate in a river community and implications for water quality modeling. Water Resources Research, 12, 723-730. 
Hunt R.J., Jardine T.D., Hamilton S.K. \& Bunn S.E. (2011) Temporal and spatial variation in ecosystem metabolism and food web carbon transfer in a wet-dry tropical river. Freshwater Biology, 57, 435-450.

Izagirre O., Agirre U., Bermejo M., Pozo J. \& Elosegi A. (2008) Environmental controls of whole-stream metabolism identified from continuous monitoring of Basque streams. Journal of the North American Benthological Society, 27, 252-268.

Jassby A.D. \& Platt T. (1976) Mathematical formulation of relationships between photosynthesis and light for plankton. Limnology and Oceanography, 21, 540-547.

Keller M., Schimel D.S., Hargrove W.W. \& Hoffman F.M. (2008) A continental strategy for the national ecological observatory network. Frontiers in Ecology and the Environment, 6, 282-284.

Koenker R. (2011) Quantreg: Quantile Regression. R Package Version 4.71.

Macintyre S., Wanninkhof R. \& Chanton J.P. (1995) Trace gas exchange across the air-water interface in freshwater and coastal marine environments. In: Biogenic Trace Gases: Measuring Emissions from Soil and Water (Eds P.A. Matson \& R.C. Harriss), pp. 52-97. Methods in Ecology. Blackwell Science, London.

Marcarelli A.M., Van Kirk R.W. \& Baxter C.V. (2010) Predicting effects of hydrologic alteration and climate change on ecosystem metabolism in a western U.S. river. Ecological Applications, 20, 2081-2088.

Martí E., Fonollà P., Von Schiller D., Sabater F., Argerich A., Ribot M. et al. (2009) Variation in stream C, N and P uptake along an altitudinal gradient: a space-for-time analogue to assess potential impacts of climate change. Hydrology Research, 40, 123-137.

Marzolf E.R., Mulholland P.J. \& Steinman A.D. (1994) Improvements to the diurnal upstream-downstream dissolved-oxygen change technique for determining wholestream metabolism in small streams. Canadian Journal of Fisheries and Aquatic Sciences, 51, 1591-1599.

Mayorga E., Aufdenkampe A.K., Masiello C.A., Krusche A.V., Hedges J.I., Quay P.D. et al. (2005) Young organic matter as a source of carbon dioxide outgassing from Amazonian rivers. Nature, 436, 538-541.

Mccutchan J.H., Lewis W.M. \& Saunders J.F. (1998) Uncertainty in the estimation of stream metabolism from open-channel oxygen concentrations. Journal of the North American Benthological Society, 17, 155-164.

Meyer J.L., Paul M.J. \& Taulbee W.K. (2005) Stream ecosystem function in urbanizing landscapes. Journal of the North American Benthological Society, 24, 602-612.

Mulholland P.J., Fellows C.S., Tank J.L., Grimm N.B., Webster J.R., Hamilton S.K. et al. (2001) Inter-biome comparison of factors controlling stream metabolism. Freshwater Biology, 46, 1503-1517.

Neter J., Wasserman W. \& Kutner M.H. (1990) Applied Linear Statistical Models. Regression, Analysis of Variance, and Experimental Design. Irwin, Homewood, IL.
Newcomer T.A., Kaushal S.S., Mayer P.M., Shields A.R., Canuel E.A., Groffman P.M. et al. (2012) Influence of natural and novel organic carbon sources on denitrification in forested, degraded-urban, and restored streams. Ecological Monographs, 82, 449-466.

Paul M.J. \& Meyer J.L. (2001) Streams in the urban landscape. Annual Review of Ecology and Systematics, 32, 333-365.

Peterson B.J., Hobbie J.E., Hershey A.E., Lock M.A., Ford T.E., Vestal J.R. et al. (1985) Transformation of a tundra river from heterotrophy to autotrophy by addition of phosphorus. Science, 229, 1383-1386.

Pinheiro J., Bates D., Debroy S., Sarkar D. \& The R Development Core Team (2011) nlme: Linear and Nonlinear Mixed Effects Models. R Package Version 3.1-101.

Platt T., Gallegos C.L. \& Harrison W.G. (1980) Photoinhibition of photosynthesis in natural assemblages of marinephytoplankton. Journal of Marine Research, 38, 687-701.

Prokopy W.R. (1992) Determination of Total Phosphorus by Flow Injection Analysis Colorimetry (Acid Persulfate Digestion Method): Quickchem Method 10-115-01-1-f. Lachat Instruments, Loveland, CO.

R Development Core Team (2011) R: A Language and Environment for Statistical Computing. R Foundation for Statistical Computing, Vienna, Austria.

Reichert P., Uehlinger U. \& Acuña V. (2009) Estimating stream metabolism from oxygen concentrations: effect of spatial heterogeneity. Journal of Geophysical Research-Biogeosciences, 114, G03016.

Roberts B.J., Mulholland P.J. \& Hill W.R. (2007) Multiple scales of temporal variability in ecosystem metabolism rates: results from 2 years of continuous monitoring in a forested headwater stream. Ecosystems, 10, 588606.

Roy A.H. \& Shuster W.D. (2009) Assessing impervious surface connectivity and applications for watershed management. Journal of the American Water Resources Association, 45, 198-209.

Runkel R.L. (1998) One-Dimensional Transport with Inflow and Storage (OTIS): A Solute Transport Model for Streams and Rivers. U.S. Geological Society, Water Resources Investigations Report 98-4018.

Runkel R.L. (2002) A new metric for determining the importance of transient storage. Journal of the North American Benthological Society, 21, 529-543.

Sardina A. (2000) Determination of Orthophosphate by Flow Injection Analysis Colorimetry: Quikchem Method 10-115-01-1-b. Lachat Instruments, Loveland, CO.

Shaffer J.M. \& Beaulieu J.J. (2012) Calibration of the odyssey $^{\mathrm{TM}}$ photosynthetic irradiance recorder ${ }^{\mathrm{TM}}$ for absolute irradiance measures. Journal of Freshwater Ecology, 27, 599-605.

Shustack D., Rodewald A. \& Waite T. (2009) Springtime in the city: exotic shrubs promote earlier greenup in urban forests. Biological Invasions, 11, 1357-1371. 
Shuster W.D., Gehring R. \& Gerken J. (2007) Prospects for enhanced groundwater recharge via infiltration of urban storm water runoff: a case study. Journal of Soil and Water Conservation, 62, 129-137.

Sinsabaugh R.L. (1997) Large-scale trends for stream benthic respiration. Journal of the North American Benthological Society, 16, 119-122.

Smith P. (2001) Determination of Ammonia (Phenolate) by Flow Injection Analysis Colorimetry: Quikchem Method 10-107-06-1-b. Lachat Instruments, Loveland, CO.

Stewart R.J., Wollheim W.M., Gooseff M.N., Briggs M.A., Jacobs J.M., Peterson B.J. et al. (2011) Separation of river network-scale nitrogen removal among the main channel and two transient storage compartments. Water Resources Research, 47, DOI: 10.1029/2010WR009896.

Stutter M.I., Demars B.O.L. \& Langan S.J. (2010) River phosphorus cycling: separating biotic and abiotic uptake during short-term changes in sewage effluent loading. Water Research, 44, 4425-4436.

Sudduth E.B., Hassett B.A., Cada P. \& Bernhardt E.S. (2011) Testing the field of dreams hypothesis: functional responses to urbanization and restoration in stream ecosystems. Ecological Applications, 21, 1972-1988.

Timoner X., Acuña V., Von Schiller D. \& Sabater S. (2012) Functional responses of stream biofilms to flow cessation, desiccation and rewetting. Freshwater Biology, 57, 1565-1578.

Uehlinger U. (2006) Annual cycle and inter-annual variability of gross primary production and ecosystem respiration in a floodprone river during a 15-year period. Freshwater Biology, 51, 938-950.

Uehlinger U., König C. \& Reichert P. (2000) Variability of photosynthesis-irradiance curves and ecosystem respiration in a small river. Freshwater Biology, 44, 493-507.

Uehlinger U. \& Naegeli M.W. (1998) Ecosystem metabolism, disturbance, and stability in a prealpine gravel bed river. Journal of the North American Benthological Society, 17, 165-178.

Walsh C.J., Roy A.H., Feminella J.W., Cottingham P.D., Groffman P.M. \& Morgan R.P. (2005) The urban stream syndrome: current knowledge and the search for a cure. Journal of the North American Benthological Society, 24, 706723.

Wanninkhof R., Mulholland P.J. \& Elwood J.W. (1990) Gasexchange rates for a 1st-order stream determined with deliberate and natural tracers. Water Resources Research, 26, 1621-1630.

Webster J.R. \& Meyer J.L. (1997) Organic matter budgets for streams: a synthesis. Journal of the North American Benthological Society, 16, 141-161.
Wendt K. (1995) Determination of Nitrate/Nitrite in Surface and Wastewaters by Flow Injection Analysis: Quikchem Method 10-107-04-1-a. Lachat Instruments, Loveland, CO.

Wetzel R.G. (2001) Limnology: Lake and River Ecosystems. Academic Press, San Diego, CA.

Young R.G. \& Huryn A.D. (1998) Comment: improvements to the diurnal upstream-downstream dissolved oxygen change technique for determining whole-stream metabolism in small streams. Canadian Journal of Fisheries and Aquatic Sciences, 55, 1784-1785.

Young R.G. \& Huryn A.D. (1999) Effects of land use on stream metabolism and organic matter turnover. Ecological Applications, 9, 1359-1376.

Yvon-Durocher G., Caffrey J.M., Cescatti A., Dossena M., Giorgio P.D., Gasol J.M. et al. (2012) Reconciling the temperature dependence of respiration across timescales and ecosystem types. Nature, 487, 472-476.

Zuur A.F., Leno E.N., Walker N.J., Saveliev A.A. \& Smith G.M. (2009) Mixed Effects Models and Extensions in Ecology with R. Springer, New York, NY.

\section{Supporting Information}

Additional Supporting Information may be found in the online version of this article:

Figure S1. Relationship between gross primary production (GPP) calculated using the two-station method and one-station method with data from the (a) downstream station and (b) upstream station. (c, d) Depict the relationship between ecosystem respiration (ER) calculated using the two-station method and the one-station method using data from the (c) downstream station and (d) upstream station.

Figure S2. Ecosystem respiration (ER) and gross primary production (GPP) calculated using the traditional twostation method (see text for details) and the method proposed by Demars et al. (2011b) which attempts to correct for spatial heterogeneity.

Table S1. Ammonium $\left(\mathrm{NH}_{4}^{+}\right)$, nitrate $\left(\mathrm{NO}_{3}^{-}\right)$, total nitrogen $(\mathrm{TN})$, soluble reactive phosphorus (SRP), total phosphorus (TP), dissolved organic carbon (DOC), total organic carbon, suspended solids concentrations (SSC) and lateral inflow (LI) rates expressed as a per cent of surface water discharge measured approximately biweekly in Shepherd Creek from July 2009 to May 2011.

(Manuscript accepted 19 December 2012) 